\title{
Communicating Corporate LGBTQ Advocacy: A Computational Comparison of the Global CSR Discourse
}

\author{
Alvin Zhou \\ Annenberg School for Communication \\ University of Pennsylvania
}

\begin{abstract}
Author Note
Pre-print version of the article published in Public Relations Review: https://doi.org/10.1016/j.pubrev.2021.102061

The manuscript, based on the author's master thesis completed at the University of Southern California and supervised by Aimei Yang, Robert Kozinets, and Larry Gross, was presented at the 102nd annual meeting of the National Communication Association as the Top Student Paper of the Public Relations Division. Additionally, I thank Rong Wang, Daniel Hopkins, Adam Khan, Shen Pan, editor, and two anonymous reviewers for their valuable comments and inputs. All remaining errors are my own. Replication materials have been deposited onto Open Science Framework at https://doi.org/10.17605/OSF.IO/5J9PT
\end{abstract}




\begin{abstract}
Corporations are increasingly engaging with political and social issues through corporate social responsibility (CSR) initiatives, in new areas such as lesbian, gay, bisexual, transgender, queer (LGBTQ) advocacy. Informed by institutional theory and stakeholder theory, this article systematically, comparatively, and computationally examines the intersection of LGBTQ advocacy and CSR communication. In particular, it contributes to the literature by 1) examining the global LGBTQ CSR discourse constructed by Fortune Global 500 companies (136,820 words) with semantic network analysis and structural topic modeling; 2) surveying non-profit organizations' guidelines and comparing corporate values with them; and 3) exploring how stakeholder expectations and institutional factors influence CSR communication. Results indicate 6 corporate topics and 9 non-profit topics, which were explicated by referencing organizations' original writing. It is further shown that stakeholder expectations and institutional factors not only affect whether or not corporations report LGBTQ efforts, but also affect what topics they highlight in CSR reports. Corporations in democratic countries with substantial stakeholder expectations emphasize areas that need high investment and exceed legal obligations.
\end{abstract}

Keywords: LGBTQ, Corporate Social Responsibility, CSR Communication, Computational Methods, Comparative Study, Corporate Activism, Institutional Theory, Stakeholder Theory 


\section{Communicating Corporate LGBTQ Advocacy:}

\section{A Computational Comparison of the Global CSR Discourse}

The past few decades have turned corporations from targets of LGBTQ activism to sources of that activism (Ball, 2019). In 2016, for example, multiple organizations, including PayPal, NBA, Target, and Apple, took a firm stand against the North Carolina House Bill 2, which sought to compel transgender individuals to use public bathrooms corresponding to their 5 birth sex (Jenkins, 2016; Surowiecki, 2016). These corporate efforts encountered intense opposition from conservative activists, lawmakers, and customers. An online petition initiated by the American Family Association to boycott $\operatorname{Target}^{1}$ was signed more than 1.5 million times, along with a huge wave of \#BoycottTarget hashtag backlash on Twitter. Subsequently, Target reported a 9.7-percent decline in earnings in the following quarter. In 2018, corporations such as Microsoft and Ernst \& Young formed a strong alliance against India's Penal Code Section 377, and have since continued to host LGBTQ-specific events in the country to raise awareness on workplace diversity (Kapur, 2020; NYU School of Law, 2019). More recently, the LGBTQ Equality Act, proposed to ban discrimination on the basis of sex, sexual orientation, and gender identity in the United States and publicly supported by only three companies in 2015, has now gathered more than 260 corporate sponsors (Human Rights Campaign, 2020).

Although these companies' actions are prone to CSR skepticism and although their motivations remain suspicious to some, the fact remains that corporations are increasingly engaging with LGBTQ issues. Yet communication scholars still know fairly little about how corporations are getting involved in the process, how they are constructing discourses around these topics, and why they might communicate their diversity-related efforts differently. This is partly because much empirical communication research on LGBTQ has been set in political and health-related domains, rarely exploring the issue in corporate and organizational settings (Anteby \& Anderson, 2014; Chan, 2017; Gross, 2005). And even when they did, LGBTQ communities were narrowly examined from the lens of business marketing, as a means to

\footnotetext{
${ }^{1}$ https://afa.net/target
} 
25 that corporations headquartered in democratic areas with high stakeholder expectations are not only more likely to report LGBTQ efforts in their CSR reports, but also more likely to devote a good deal of space to topics that exceed legal obligations (i.e., discrimination prevention). The effect of stakeholder expectations was robust when institutional factors were held constant. 


\section{Organizations and LGBTQ}

Notwithstanding its prominence in popular culture, LGBTQ issues still constitute an emerging topic in communication and public relations research. Compared to other minority groups (e.g., based on gender, race, national origin, and religion), the LGBTQ communities have a relatively short history of issue advocacy, and the majority of LGBTQ individuals across the globe are not protected from employment discrimination by national legal systems (Hebl et al., 2020). The United States, for example, only guaranteed constitutional employment protections for LGBTQ people very recently on June 15, 2020 through a landmark Supreme Court case. In fact, as of 2019, 68 countries of all United Nations (UN) member states still criminalized same-sex sexual acts, the institution of marriage for same-sex couples was only provided by 26 member states, and the constitutional protection against discrimination based on sexual orientation existed for only 3 member states (Mendos, 2019). More broadly, LGBTQ individuals still experience both explicit and implicit forms of discrimination and harassment in many aspects of life, including the workplace (Tilcsik, 2011).

Before going further, it bears emphasis that the acronym "LGBTQ" encompasses issues the all-encompassing term tend to standardize diversity, conceal differences, and reinforce exclusion (Formby, 2017) - the exact opposite of what queer theorists and communication scholars queering the discipline advocate (Butler, 2006; Ciszek, 2018; McDonald, 2015). However, since corporate discourses and non-profit organizations address these issues in conjunction, as demonstrated below, we take an empirical approach similar to Chan (2017) and García-Jiménez et al. (2021), use this generic expression to collect and examine organizations' 
communication archives, and recognize this limitation due to practicality.

Despite the aforementioned low pace of public policy change at the global level, it cannot be denied that LGBTQ activists have had major wins in the past century (Githens, 2009). communicated through CSR reports, bear significance to the study of CSR communication and strategic communication at large. In a review of communication scholarship on LGBTQ issues, Chan (2017) cited Tindall and Waters's (2013) argument that "LGBTQ issues have largely been neglected by scholars in the strategic communication field, including advertising, public relations, and marketing" (p. 2658) and called for more scholars to investigate the practice of LGBTQ-related communication in these subfields.

Accordingly, Sha and Ford (2007) argued that public relations scholarship on diversity issues should cover three areas: 1) public relations practitioners who identify as minorities; 2) sexual and gender minorities as audiences of communication messages; and 3) the role of organizational communication in diversity issue management. However, a large portion of studies on diversity issues was conducted in the first two areas which investigated LGBTQ individuals' lived experiences either as employees or as customers. For example, Tindall and 
Waters (2012) tried to understand gay public relations practitioners' special concerns in the workplace with in-depth interviews and focus groups, which falls into the first area. Hon and Brunner (2000) and Toledano and Riches (2014), among others (e.g., Rodriguez, 2016), saw LGBTQ individuals as potential audiences of communication campaigns, and contended that in response to the globalization and diversification of audiences, organizations' public communication should also be practiced by diverse employees to effectively match with audience attributes, which covers the second area. The third area, which sees LGBTQ as a social issue for organizations, especially corporations, to manage and engage, was left much unattended (c.f., Amazeen, 2011; Capizzo, 2020).

Thus, extant communication scholarship at the intersection of LGBTQ and organizations, examining either LGBTQ employee experiences or LGBTQ audiences/consumers, constitutes a narrow focus on how organizations interact with such broad issues as LGBTQ rights and fails to illustrate the significant passage of corporate responsibility through which the function of public relations has positively contributed to the visibility of LGBTQ identities (Ciszek, 2020; Edwards, 2015; Edwards \& L’Etang, 2013). This study, therefore, first tries to fill the knowledge gap by examining the communication of CSR practice as corporations' issue management efforts and providing an overview of the global CSR discourses constructed by leading corporations.

RQ1: What is major global corporations' CSR discourse around LGBTQ issues?

It should be noted that, with many large corporations getting increasingly vocal on diversity issues, there have been heated discussions - and sometimes harsh criticisms - on corporate involvement in LGBTQ activism. The general public has questioned these corporations' intentions, and scholars have argued that, by adopting LGBTQ-friendly policies and engaging with LGBTQ activism, some corporations merely want to capture the lucrative queer consumer market for the sake of firm performance (e.g., J. E. Campbell, 2005). This kind of practice has been referred to as pinkwashing (Schulman, 2011). For example, Keystone Pipeline System, an oil pipeline project in Canada and the United States, tried to draw public 
support by comparing Canada's record on LGBTQ rights with other nations, while not devoting any real corporate resources to LGBTQ advocacy (Michaelson, 2014). In other words, by pinkwashing, businesses do not invest in the issue itself or challenge inequalities in society, but instead profit from it, which translates to them taking LGBTQ advocacy as opportunities instead of responsibilities. Although it is difficult to pinpoint the differences between CSR practice and CSR communication for each company in this empirical study, the phenomenon of pinkwashing, along with the quest to find an altruistic prior to identify topics in the corporate corpus, makes it necessary for the current study to seek non-profit organizations' guidelines as the benchmark, against which we can empirically critique the corporate discourse.

RQ2: How does the global LGBTQ CSR discourse compare with non-profit LGBTQ organizations' guidelines?

\section{Corporate Social Responsibility}

Traditionally, corporations are only responsible for delivering services to clients and maximizing financial returns to investors. But since the mid-20th century, consumers and governments have increasingly extended their expectations and definition of corporate responsibilities, and businesses in response have started taking employees, suppliers, local communities, and other stakeholders into account during their decision-making processes (Carroll, 1991, 1999; Johnson, 1971).

Corporate social responsibility is typically understood as corporations' economic, legal, responsibilities from the scope of CSR. 
The issue of whether economic and legal responsibilities count as social responsibilities is of considerable relevance for our cross-national examination of diversity-related CSR regional factors can influence and sometimes determine corporate communication.

Scholars who comparatively studied business ethics have been using the institutional theory to explain these between-corporation differences in terms of CSR practice and 
185

communication (e.g., Doh \& Guay, 2006; O’Connor \& Shumate, 2010). The institutional theory argues that institutional factors, such as political structures and industrial norms, drive isomorphic changes and make organizations more similar to each other if they share certain characteristics (i.e., industries, country, democracy level, etc.), including their communication practice of corporate social responsibility (J. L. Campbell, 2007; DiMaggio \& Powell, 1983; Lammers \& Barbour, 2006; O’Connor \& Gronewold, 2013; Scott, 1995; Shumate \& O’Connor, 2010; Yang \& Liu, 2018).

Drawing upon these studies along with others that showed effects of institutional factors on firm management and CSR communication (e.g., Lattemann et al., 2009; O'Connor \& Shumate, 2010; Scholtens \& Dam, 2007), this study also took a comparative approach to the examination of global CSR practice. More specifically, we not only present common themes of the global CSR discourse on LGBTQ issues, but also pay special attention to the differences among corporations, and explore whether variances in CSR reporting on LGBTQ advocacy can be attributed to institutional factors across countries.

The level of protection for LGBTQ individuals still drastically varies across countries, from Mexico where same-sex marriage was legalized in 2009 and anti-discrimination law was passed in 2011, to Saudi Arabia where no LGBTQ advocacy groups were operating and sexual minorities continued to be persecuted (Adamczyk \& Liao, 2019; Mendos, 2019). These institutional differences have significant influences on how corporations communicate their commitment to social responsibilities (O’Connor \& Gronewold, 2013). Since LGBTQ advocacy is usually considered part of the human rights issue that correlates with democratic values and civil liberty (Davenport \& Armstrong, 2004; Donnelly, 1999), we would suspect that corporations located in countries with higher levels of democracy, civil liberty, and legal protections against LGBTQ discrimination would be more likely to relay their efforts on LGBTQ advocacy in their CSR reports, while those located in countries with lower such levels would be less likely to communicate their commitment. Levels of democracy, civil liberty, and LGBTQ legal protections are well studied and numerically indexed in the political science and 
international relations literature, which this study adopts and will be explained in more detail in later sections. Moreover, as suggested by research agencies and non-profit organizations (e.g., Mendos, 2019; Poushter \& Kent, 2020), the global divide of institutional LGBTQ protection political science literature has suggested that the traditional industry ideologically leans conservative according to their corporate political expenditures (e.g., Bonica, 2014) and might 
less likely engage with a liberal issue such as LGBTQ advocacy, compared to services (including

the sectors of consumer discretionary, consumer staples, financials, and health care, and companies such as Walt Disney, Chase, and Allstate) and high tech (including the sectors of technology and telecommunications, and companies such as Apple, IBM, and Facebook). Our three-way industry classification references the Industry Classification Benchmark (ICB), the Standard Industrial Classification (SIC), and the scheme developed by Zéghal and Maaloul (2010). With more details presented in Table 1 of the online Appendix, we hypothesize:

H1c: Corporations in the traditional industry are less likely to communicate LGBTQ advocacy in CSR reporting than those in the services and high tech industries.

Another theoretical framework that has proven to be valuable in comparative examinations of CSR communication is the stakeholder theory (Donaldson \& Preston, 1995; Freeman, 1984). CSR practice, especially those conducted on ethical and philanthropic grounds, is in many cases communicated to influence stakeholder perceptions (Costa \& Menichini, 2013; Sweeney \& Coughlan, 2008). By considering who the audiences of their CSR communication are, corporations are likely to curate their discourses around social issues to align with the preferences of their immediate public - the general population (Morsing \& Schultz, 2006). In other words, corporations that operate in places where social acceptance of LGBTQ individuals is low, in fear of public opposition, might be reluctant to communicate their LGBTQ commitments in formal publications. In contrast, corporations headquartered in places with higher levels of acceptance might conform with the respective social norms and report their LGBTQ efforts to elicit positive responses, fulfill stakeholder expectations, and gain sociopolitical legitimacy (Capizzo, 2020; Wang \& Qian, 2011). Therefore, we also investigate how the level of LGBTQ acceptance, which proxies the level of social expectations for companies to make LGBTQ-related CSR efforts, might influence corporations' CSR discourse, and hypothesize:

H1d: Corporations headquartered in countries with higher levels of LGBTQ acceptance are more likely to communicate LGBTQ advocacy in CSR reporting than those with lower levels. 


\section{Non-Profit Guidelines for Corporate LGBTQ Advocacy}

Before diving into how corporations construct their CSR discourses around LGBTQ issues, we first examine the advice non-profit organizations issue to corporations for LGBTQ advocacy. As mentioned earlier, enlisting guidelines written by non-profit organizations and

The hierarchy of corporate LGBTQ commitments recommended by non-profit organizations suggests another set of communication patterns that might exist in corporations' CSR reporting. For example, companies located in areas with low acceptance of LGBTQ

\footnotetext{
2 The final eight reports consulted are the Building LGBT-inclusive Workplace report from Catalyst, the Studio Responsibility Index 2019 from GLAAD, the Corporate Equality Index 2020 from HRC, the State-Sponsored Homophobia 2019 from ILGA, the Providing Inclusive Services and Care for LGBT People report from National LGBT Health Education Center, the Model Contract Language report from Pride At Work, the Workplace Equality Index 2020 from The Stonewall, and the Workplace Pride Global Benchmark 2017 from Workplace Pride.
} 
individuals might just cover basic obligations (e.g., anti-discrimination policies) and dismiss

expectations that require more investment (e.g., monetary contributions). In contrast, companies that endure higher democratic and stakeholder pressures might emphasize how they devote extra resources to areas that exceed expectations in their CSR communication. Therefore, similar to the first set of hypotheses developed earlier, we speculate:

H2a: Corporations in North America and Europe will give less emphasis to low-investment LGBTQ efforts in CSR reporting than those in Asia.

H2b: Corporations headquartered in countries with higher levels of democracy (H2b1), civil liberty (H2b2), and legal protections (H2b3) will give less emphasis to low-investment LGBTQ efforts in CSR reporting, compared to those with lower levels of democracy, civil liberty, and legal protections.

H2c: Corporations in the traditional industry will give more emphasis to low-investment LGBTQ efforts in CSR reporting than those in the services and high tech industries.

H2d: Corporations headquartered in countries with higher levels of LGBTQ acceptance will give less emphasis to low-investment LGBTQ efforts in CSR reporting than those with lower levels.

\section{Data and Method}

Conducting a large-scale cross-national study on CSR communication is challenging, and comparative studies in this domain are still relatively rare. The limited collection of comparative studies on CSR communication focused on a few countries, using interviews, surveys, or content analysis. For example, employing manual coding, Maignan and Ralston (2002) compared the communication practice of companies located in France, the Netherlands, the U.K., and the U.S. on their websites, and presented their different levels of dedication and commitment to CSR. These qualitative and quantitative methods are usually not scalable and fail to utilize the accumulating empirical data of CSR communication for comparative analyses. In this study, we argue that the huge potential of computational methods for communication research can be realized for comparative endeavors (e.g., Lucas et al., 2015; van der Meer, 2016). 
Tools developed by computational social scientists have provided communication scholars a new way to conduct rigorous analyses on big textual datasets, which could not have been envisaged as a possibility by previous studies (van Atteveldt \& Peng, 2018). We explicate our data collection and computational methods in the following subsections. Aligning ourselves with principles of open science and data transparency, we have deposited the dataset, scripts, and relevant files (e.g., non-profit reports) on Open Science Framework (OSF) for replication purposes.

\section{Data Collection}

We collected and examined the annual CSR reports of companies on the 2018 Fortune Global 500 list. Fortune Global 500 companies were selected for three reasons. First, companies on the list are from different countries and industries with various political and social backgrounds, which introduces the variances necessary for this comparative study. Second, Fortune Global 500 companies have larger revenues, more stakeholders, and higher visibility in their countries than companies with smaller volumes. Therefore, they arguably contribute more corporate resources to CSR causes and communicate their CSR efforts more actively. Third, with a larger number of stakeholders, a Fortune Global 500 company may have more LGBTQ stakeholders proportionally. The higher visibility of LGBTQ members could elicit more corporate attention to the communities. Using companies more active in CSR reporting and more engaged with the LGBTQ communities can facilitate our data collection and analysis.

Fortune Global 500 companies use various methods for annual CSR reporting. Most companies offer their CSR reports as downloadable PDFs, using names such as CSR Report, Sustainability Report, Corporate Citizenship Report, ESG (Environmental, Social, and Governance) Report, and other variations. Others adopt online website reporting, and some do not implement CSR reporting at all. To avoid biases and to fairly compare companies, we collect and analyze English CSR communication reports in the form of PDF publications. In cases where corporations explicitly stated that CSR reports were incorporated into general reporting, we used the CSR sections in annual and integrated reports or registration documents. We manually 
downloaded the most recent CSR report of each company published in the past 5 years. The exact coverage of "fiscal year" differs across companies, and therefore some collected reports were named as their 2018 report, with others named as 2017 or 2019. Data were collected in mid-2019. This data collection procedure was set in place to collect data as recent, official, and extensive as possible at the intersection of corporate LGBTQ advocacy and CSR communication.

These documents were then manually searched for thirteen search terms concerning LGBTQ issues: LGBT, gay, lesbian, bisexual, transgender, queer, homosexual, sex, orientation, preference, gender, identity, and pride. In the following analyses, we used the textual data of the context in which these terms were used. In most cases, the context was the paragraphs under the same subheading.

Among these Fortune Global 500 companies, 406 of them published CSR reports which we collected and manually searched for the thirteen keywords. Among these 406 companies, 236 mentioned at least one LGBTQ-related word in their CSR reports. Our corpus thus contains 236 documents and their 136,820 words and 8,287 unigrams. More details about data collection, descriptive results, and corpus construction can be found in the online Appendix.

\section{Data Labeling}

Covariates that might affect how companies $(N=236)$ constructed their LGBTQ CSR discourses were reviewed in previous sections. Below, we detail data sources and some descriptive results of each variable for the whole dataset.

Ranking, Country, and Continent. The Fortune Global 500 list provided the ranking number and headquarter location of each company. Thirty-three countries were represented on the list, 25 of which contained companies that mentioned LGBTQ issues. We matched the geographical information to five continents: North America $(N=77)$, Europe $(N=91)$, Asia $(N=56)$, Oceania $(N=7)$, and South America $(N=5)$.

Industry. We used companies' industry information provided by Fortune for further classification. Consulting the Standard Industrial Classification (SIC) and Industry Classification Benchmark (ICB), both widely used by scholars and financial sectors for categorization (e.g., 
NYSE, NASDAQ, Arun et al., 2015; Yang et al., 2020), we classified the 2018 Fortune Global 500 companies into three categories: traditional $(N=62)$, services $(N=140)$, and high tech $(N=34)$, similar to Zéghal and Maaloul (2010). The detailed classification scheme can be found in Table 1 of the online Appendix.

Democracy. Each country's democracy level was marked by the latest Polity score from the Polity Project (Marshall \& Gurr, 2020), which has been widely used and validated in political science, economics, and sociology literature (e.g., Brückner \& Ciccone, 2011; Cole, 2005). The score ranges from -10 (hereditary monarchy) to +10 (consolidated democracy) on a 21-point scale in our dataset $(M=5.22, S D=6.78)$.

Civil Liberty. The International Institute for Democracy and Electoral Assistance provided the annual Global State of Democracy Indices, which assessed the subarea of civil liberty (e.g., freedom of expression and personal integrity) across 158 countries in 2018 (Skaaning, 2019). The score ranges continuously from 0 (no civil liberty) to 1 (full civil liberty), and has one missing data on Luxembourg in our dataset $(M=.72, S D=.24)$.

Legal Protection. The International Lesbian, Gay, Bisexual, Trans, and Intersex Association (ILGA) publishes annual reports on state-sponsored homophobia, which assess the degree to which each country legally protects minorities against sexual orientation discrimination (Mendos, 2019). The score ranges from -4 (death penalty for consensual same-sex acts) to +4 (constitutional protection against discrimination) on a 9-point scale $(M=1.43, S D=1.28)$

Social Acceptance. Each country’s LGBTQ social acceptance data come from the Social Acceptance of LGBT People in 174 Countries report published by the William Institute, which compiled 5 million survey responses to questions on the general public's beliefs on LGBTQ individuals (Flores, 2019). The score ranges from 0 (low social acceptance) to 10 (high social acceptance) on an 11-point scale, and has one missing data on the United Arab Emirates in our dataset $(M=6.12, S D=1.59)$. 


\section{Data Analysis}

The combination of semantic network analysis and structural topic modeling was used to present and compare the global CSR discourse on LGBTQ advocacy. Semantic network analysis, by revealing relations among concepts, helps demonstrate the meaning creation in corporations' discourse on a certain issue (Doerfel \& Barnett, 1999; Yang \& Veil, 2017). The method is particularly valuable for research that examines organizations' narratives and discourses, such as values advocacy, CSR communication, and crisis responses (Schultz et al., 2012; Zhou, 2019). In this study, we use semantic network analysis to uncover the linguistic associations among words that are used by corporations when they discuss LGBTQ advocacy as a commitment to social responsibilities, which will give us a general picture of the big textual dataset.

Structural topic modeling (STM), an unsupervised machine learning method, was used to investigate topical patterns in our corpus. Topic modeling such as STM is not dictionary-based; instead, it analyzes patterns of term co-occurrences and clusters these co-occurring terms together as topics for human interpretation (Grimmer \& Stewart, 2013). Therefore, topic modeling can also be understood as a dimension reduction method, in the sense that the method simplifies and categorizes the universe of document unigrams - a system with complex linguistic meaning - into a limited number of topics (dimensions). During the process, unigrams that do not clearly belong to any topic might form a filler topic that is generic in its meaning as interpreted by human readers (Crain et al., 2012). Topic modeling methods assume each document is a mix of several topics, with each document having different emphases and hence different topical proportions. We use the variances in topical proportions in the model to test our second set of hypotheses.

One major innovation of structural topic modeling, compared to more traditional methods such as the Latent Dirichlet Allocation model, is that it allows researchers to incorporate document metadata into the computing process (Roberts et al., 2019). By linking topical results (such as the proportion of each topic in documents) with covariates, the method 
is particularly useful for comparative studies that explore the relationship between covariates and communication emphases. For example, by adding conditions (treatment or control) as covariates to documents, scholars are now able to estimate the treatment effect of an intervention on how people construct their meaning around certain issues (e.g., Roberts et al., 2014). Similarly, Lucas et al. (2015) labeled documents with their origins as covariates (either China or the Middle East) and demonstrated how the two countries' citizens differed in what substantive topics they focused on when posting online about an international event. Applied to our case, structural topic modeling can help us test hypotheses on topical emphases by labeling Fortune Global 500 companies with their institutional and stakeholder-related covariates.

Upon data cleaning, including document-feature matrix construction, frequency threshold-based feature selection, and stopword removal, we estimated the topic model with the number of topics ranging from 3 to 10 , per the NGO guidelines discussed earlier. The model diagnosis along with human reading suggested the 7-topic result which includes one filler topic and six substantive topics on CSR LGBTQ Advocacy. The 6 topics will be explicated in the result section, with more methodological transparency provided in the Online Appendix.

\section{Results}

\section{RQ1 and RQ2: CSR versus Non-Profit Discourse on Corporate LGBTQ Advocacy} around LGBTQ issues. To this end, we conducted semantic network analysis and structural topic modeling, with results respectively shown in Figure 1 and Table 2.

[Insert Figure 1 and Table 2 Here]

In our semantic network (Figure 1), the tie width corresponds to the number of corporations that used the two words in their documents, and the label size corresponds to the word's weight. The visualization, only showing the top 50 words after backbone extraction (Serrano et al., 2009), shows that Fortune Global 500 corporations' CSR discourse on LGBTQ advocacy mainly focuses on creating diverse and inclusive workplaces for their employees, 
signaled by the centrality of words that are used mostly for internal contexts (i.e., employee,

450 employment, workplace, and team). Consequently, their narratives usually mention other diversity-related attributes describing employees such as gender and disability. Several non-profit guidelines uncovered earlier were also visible at the core of our network. For example, words around "human rights" suggest a semantic cluster that focuses on the prevention of discrimination and the necessity of training in the workplace. Efforts on external LGBTQ stakeholders were also present albeit not central in the network, an example being the cluster around "supplier programs" which focuses on diversifying procurement pools to support more minority-owned providers.

To answer RQ2, we use structural topic modeling to cluster the collected text into topics and compare those corporate topics with non-profit guidelines. The model result, shown in Table 2, suggests six distinct corporate topics that could all be found in the NGO guidelines on LGBTQ advocacy (Table 1). However, three NGO recommendations were absent in the corporate discourse, i.e., the measurement of diversity performance for leadership positions, the implementation of data collection on queer individuals, and the philanthropic and monetary support for external LGBTQ advocacy organizations. In Table 2 we also listed words most likely to be associated with the topic (High Probability) and most likely to be distinguishable from other topics (High Exclusivity) to help explicate these six corporate topics. Structural topic modeling's raw data output, along with word clouds and model diagnostics, is provided in the Online Appendix.

Below, from the low level of investment to the high level of investment, we briefly explicate each topic using the relevant words in Table 2 to provide more context on how each topic was discussed by examined corporations. Organizations on average emphasized the most on their legal obligations (Label: Discrimination; Proportion: 20.1\%) as they reiterated corporate policies on discrimination and harassment. For example, Quanta Computer wrote that they "fulfill its anti-discrimination commitments and prohibit the discrimination of people based on ethnicity, skin color, age, gender, sexual orientation, race, disabilities, pregnancy, religious and 
political beliefs, membership in social groups, or marital status." This finding suggests that companies' communication patterns might also conform with the pyramid model (Carroll, 1991), in that it emphasizes corporations' fulfillment of lower-level responsibilities (i.e., legal obligations). Next, using examples of their human rights seminars, these corporations tried to demonstrate how they raised awareness of LGBTQ issues within their companies (Label: Training; Proportion: 14.2\%). For example, Mazda wrote in its CSR report that they started "organizing training programs and lectures to promote understanding of sexual minority (LGBT) issues" in early 2017. Organizational culture (Label: Culture; Proportion: 18.0\%) is the next topic mentioned in corporations' writing, where they show a strong commitment to creating an inclusive and welcoming culture for everyone. Support for LGBTQ-owned suppliers also constitutes a major topic (Label: Supplier; Proportion: 10.4\%). For example, IBM spared several sections in its CSR report on supplier diversity and communicated its dedication to LGBTQ-owned businesses. The second most emphasized topic across all examined corporations is establishing colleague networks through Employee Resources Groups (ERGs) (Label: Networks; Proportion: 14.4\%). For example, Dell documented how it established new chapters of its employee resource group for sexual minority members and allies "in locations where identifying as LGBT is not widely accepted." Last, some organizations detailed how they extended healthcare benefits to LGBTQ employees' partners and made new strides at transgender healthcare (Label: Benefit; Proportion: 10.7\%). For example, Raytheon claimed in its CSR report to be among the first in the Aerospace Defense industry to offer same-sex domestic partner benefits, and Bank of America claimed to be the first major company in the United Kingdom to include gender reassignment surgery for employees in its health insurance package.

\section{Hypothesis Testing: Institutional and Stakeholder Factors in LGBTQ CSR}

\section{Communication}

Now we turn to hypothesis testing on how politics, stakeholders, and industry types affect whether corporations communicate LGBTQ efforts in CSR reports (H1) and what topics they emphasize in CSR communication (H2). The results are summarized in Table 3. 
[Insert Table 3 Here]

To examine the first set of hypotheses (H1) about the likelihood to communicate CSR using logistic regression. Table 4 shows that proposed hypotheses are all supported, as corporations in North America $(b=1.35, p<.001)$ and Europe $(b=1.14, p<.001)$ or in the services $(b=.46, p<.05)$ and high tech $(b=1.29, p<.01)$ industries are more likely to communicate CSR efforts on LGBTQ issues. Indicators on the political environment of the headquartered country are also significant, as companies in democratic $(b=.17, p<.001)$ and civil liberal $(b=5.25, p<.001)$ countries with better legal protections against sexuality discrimination $(b=.47, p<.001)$ are more likely to communicate their commitment to the communities. Stakeholder expectation, proxied as the general population's average social acceptance of LGBTQ individuals, is also a statistically significant predictor $(b=.55, p<.001)$. Table 4 treats companies that do not publish CSR reports as missing data. Its result on statistical significance remains robust when the regression model treats companies that do not publish CSR reports as if they do not mention LGBTQ issues.

\section{[Insert Table 4 Here]}

To examine the second set of hypotheses (H2) on how companies differ in terms of their communicative emphases, we focus on the low-investment topic of anti-discrimination policy for LGBTQ individuals, which in many cases only helps companies assume their legal responsibilities. By regressing this topical proportion on the same set of corporate variables, Table 5 shows that companies based in North America are significantly less likely to detail their anti-discrimination policies in CSR reports $(b=-.22, p<.001)$ compared to those based in Asia. The effect of Europe is in the hypothesized direction but not statistically significant $(b=-.06, p=.19)$. Two political indicators are both statistically significant and negative, as companies headquartered in countries that are more democratic $(b=-.02, p<.05)$ and enjoy 
higher levels of civil liberty $(b=-.75, p<.001)$ are less likely to spare unnecessary space for

anti-discrimination policies that might have been a given. However, the level of legal protections for LGBTQ individuals positively predicts the topical proportion devoted to companies' communication on anti-discrimination policies, contrary to the hypothesis $(b=.05, p<.01)$. Stakeholder expectation also makes companies pay more attention to discussions on high-investment areas $(b=-.05, p<.01)$. And the model suggests that the proportion devoted to legal responsibilities does not differ significantly across industries.

[Insert Table 5 Here]

The procedure of linearly regressing topical proportions on covariates did not approximate the STM model's measurement uncertainty (Roberts et al., 2019), and thus might underestimate standard deviations of some covariates' effects in Table 5. To provide a robustness check, we included a more conservative measure of covariates' effects by using global approximation, reported in Figure 4 of the online Appendix. The directional effects of these covariates are mostly robust according to the alternative method, except the effects of democracy and state-level legal protection become marginally significant.

In summary of our findings on H1 (Table 4), we find that institutional factors can well predict whether Fortune Global 500 companies' CSR reports communicate LGBTQ advocacy. Corporations located in more democratic countries with higher civil liberty indexes and higher levels of legal protection tend to mention LGBTQ issues more frequently. The influence of institutional factors is particularly striking when we compare Mainland China and Taiwan, two regions that share much similar cultural and linguistic backgrounds but have drastically different political environments for sexual minorities. As Taiwan became the first in Asia to legalize same-sex marriage in 2019, Mainland China continues to be an unwelcoming place for LGBTQ individuals politically. In our dataset, only 6 out of the 59 companies in Mainland China mentioned LGBTQ-related terms in their CSR reports, while 7 out of the 9 companies in Taiwan communicated their commitment to LGBTQ stakeholders. Geographically, we find companies located in North America and Europe more likely to address sexuality issues in their corporate 
reports. Using the population's social acceptance of LGBTQ individuals as our proxy, we find that companies tend to align with stakeholder expectation and communicate their LGBTQ efforts if the public support sexual equality. Interestingly, if we regress the dummy variable on stakeholder expectation while holding state-level legal protection constant, which enables us to disentangle the effect of social pressure from institutional factors, we still find companies with higher stakeholder expectation to more likely communicate LGBTQ efforts in their CSR reports $(b=.25, p<.05)$. In other words, the effect of stakeholder expectation remains robust, if we narrow our analysis to smaller areas such as Northern Europe and South Asia where state-level legal protection is the same across countries.

In summary of our findings on H2 (Table 5), we find the results to generally fall in line with the hypotheses. Companies located in democratic countries with high civil liberty stressed their ethical and philanthropic responsibilities, while companies in autocratic countries with low civil liberty merely stated their legal obligations. Stakeholder expectation also significantly affects CSR communication in terms of topical proportion. Similar to what we did above, if we regress the topical proportion on stakeholder expectation while holding state-level legal protection constant, we likewise find companies with higher stakeholder expectation to emphasize less on anti-discrimination policies in their CSR reports $(b=-0.08, p<.001)$. Thus, our findings on $\mathrm{H} 2$ align with the predictions from the pyramid model of corporate social responsibility (Carroll, 1991), but also extend it by showing that the hierarchy of corporate social responsibilities also manifests through CSR communication.

\section{Discussion}

The LGBTQ communities have swiftly risen to high visibility during the past few decades, thanks to advocates and allies' persistent political activism (Adam, 1987). Corporations, meanwhile, have also entered the public dialogue by taking social responsibility initiatives, and tried to influence their economic and institutional environments through values advocacy (Bostdorff \& Vibbert, 1994; Xu \& Zhou, 2020). The communication of corporate social responsibilities constitutes a critical part of organizational rhetoric during this advocacy, which 
underscores the critical role of public relations in contemporary societies (O'Connor \& Ihlen, 2018; Schoeneborn \& Trittin, 2013). Going forward, as the corporate environment gets

Lastly, we applied newly developed computational methods to assist our data analysis on large corporate corpora, a niche area which was highlighted by prior research (van der Meer, 2016) but has not yet received considerable development in recent publications. By demonstrating how these methods could help scale up empirical analyses - especially in comparative studies 

to consider the values of computational social science for public relations research.

\section{Limitations and Future Research}

Admittedly, the study is limited by its sample of Fortune Global 500 companies, a revenue-based ranking list that over-represents the Global North. However, as the practice of
615 symbol of Western imperialism in many developing countries (Khan \& Lund-Thomsen, 2011), accessing a more representative sample of global companies is challenging. Moreover, the issue of gender and sexual diversity, in and of itself, is oftentimes considered Western interference (Epprecht, 2013). For example, Currier and Cruz (2020) described how Barack Obama’s declaration of support for LGBTQ rights instilled concerns and fueled local anti-gay mobilization in Liberia, which shed light on how sexuality, race, colonialism, and public diplomacy could interplay in local politics. The study thus presents opportunities for future fieldwork to further our understanding of how sexual minorities (and any other marginalized publics) exert influences on social responsibility practice and communication in Global South corporations. Taking a qualitative or ethnographic approach, by observing the dynamic process of meaning construction within a specific organization and inquiring about the forces behind the final product of CSR discourse as reported by the current study, can also help answer the broader question of how organizational rhetoric is negotiated within its hierarchical structure.

Collecting textual data to provide a descriptive account of the global CSR discourse on LGBTQ issues was one of the study's goals. However, the dataset with its cross-sectional nature cannot precisely reveal the causal link between external factors and corporate rhetoric. Future research can employ longitudinal data to better explore this issue. For example, Lucas et al. (2015) showed the potential of using structural topic modeling to detect temporal changes in textual data. By collecting years of corporate reports, modeling topical proportions as the dependent variable, and marking significant events as discontinuity points, studies can tap into how political episodes, such as the passage of LGBTQ-friendly legislation, could have influenced 
CSR communication. Another way to move the literature forward is by identifying cases where a multinational corporation adjusts its issue-based CSR practice and communication on a region-by-region basis. For example, the Virgin group has terminated trade with Uganda since the introduction of its anti-homosexuality bill, but kept its business running in other African countries (Labott \& Farshbaf, 2013). Single-company multiple-country cases similar to this might provide better opportunities for future studies to claim causal identification.

Creating strict data collection criteria and only using official publications also limited us from constructing a bigger dataset or investigating more interactive communication formats, such as social media posts and website communication. By considering what kinds of stakeholders would be drawn to each format and examining differences between the content posted in these formats, in terms of language differences and topical proportions, future research can provide more insights on how stakeholder demographics and characteristics might influence organizations' communication on their CSR practice. 


\section{References}

Adam, B. D. (1987). The rise of a gay and lesbian movement. Twayne.

Adamczyk, A., \& Liao, Y.-C. (2019). Examining public opinion about LGBTQ-related issues in the United States and across multiple nations. Annual Review of Sociology, 45(1), 401-423. https://doi.org/10.1146/annurev-soc-073018-022332

Amazeen, M. (2011). Gap (RED): Social responsibility campaign or window dressing? fournal of Business Ethics, 99(2), 167-182. https://doi.org/10.1007/s10551-010-0647-2

Anteby, M., \& Anderson, C. (2014). The shifting landscape of LGBT organizational research. Research in Organizational Behavior, 34, 3-25. https://doi.org/10.1016/j.riob.2014.08.001

Arun, T. G., Almahrog, Y. E., \& Ali Aribi, Z. (2015). Female directors and earnings management: Evidence from UK companies. International Review of Financial Analysis, 39, 137-146. https://doi.org/10.1016/j.irfa.2015.03.002

Ball, C. A. (2019). The queering of corporate America: How big business went from LGBTQ adversary to ally. Beacon Press.

Bonica, A. (2014). Mapping the ideological marketplace. American fournal of Political Science, 58(2), 367-386. https://doi.org/10.1111/ajps.12062

Bostdorff, D. M., \& Vibbert, S. L. (1994). Values advocacy: Enhancing organizational images, deflecting public criticism, and grounding future arguments. Public Relations Review, 20(2), 141-158. https://doi.org/10.1016/0363-8111(94)90055-8

Brückner, M., \& Ciccone, A. (2011). Rain and the democratic window of opportunity. Econometrica, 79(3), 923-947. https://doi.org/10.3982/ECTA8183

Butler, J. (2006). Gender trouble: Feminism and the subversion of identity. Routledge.

Campbell, J. E. (2005). Outing PlanetOut: Surveillance, gay marketing and internet affinity portals. New Media \& Society, 7(5), 663-683. https://doi.org/10.1177/1461444805056011

Campbell, J. L. (2007). Why would corporations behave in socially responsible ways? An institutional theory of corporate social responsibility. Academy of Management Review, 32(3), 946-967. https://doi.org/10.5465/amr.2007.25275684 
Capizzo, L. (2020). The right side of history, inc.: Social issues management, social license to operate, and the Obergefell v. Hodges decision. Public Relations Review, 46(5), 101957. https://doi.org/10.1016/j.pubrev.2020.101957

Carroll, A. B. (1979). A three-dimensional conceptual model of corporate performance. Academy of Management Review, 4(4), 497. https://doi.org/10.2307/257850

Carroll, A. B. (1991). The pyramid of corporate social responsibility: Toward the moral management of organizational stakeholders. Business Horizons, 34(4), 39-48. https://doi.org/10.1016/0007-6813(91)90005-G

Carroll, A. B. (1999). Corporate social responsibility: Evolution of a definitional construct. Business \& Society, 38(3), 268-295. https://doi.org/10.1177/000765039903800303

Chan, L. S. (2017). Emerging currents in communication/LGBTQ studies: A review of LGBTQ-related articles published in communication journals from 2010 to 2015. International fournal of Communication, 11, 2647-2668.

Chintrakarn, P., Treepongkaruna, S., Jiraporn, P., \& Lee, S. M. (2020). Do LGBT-supportive corporate policies improve credit ratings? An instrumental-variable analysis. Fournal of Business Ethics, 162(1), 31-45. https://doi.org/10.1007/s10551-018-4009-9

Ciszek, E. L. (2017). Activist strategic communication for social change: A transnational case study of lesbian, gay, bisexual, and transgender activism. Journal of Communication, 67(5), 702-718. https://doi.org/10.1111/jcom.12319

Ciszek, E. L. (2018). Queering PR: Directions in theory and research for public relations scholarship. Fournal of Public Relations Research, 30(4), 134-145. https://doi.org/10.1080/1062726X.2018.1440354

Ciszek, E. L. (2020). "We are people, not transactions": Trust as a precursor to dialogue with LGBTQ publics. Public Relations Review, 46(1), 101759. https://doi.org/10.1016/j.pubrev.2019.02.003 
Ciszek, E. L., \& Rodriguez, N. S. (2020). Power, agency and resistance in public relations: A queer of color critique of the Houston Equal Rights Ordinance. Communication, Culture and Critique, 13(4), 536-555. https://doi.org/10.1093/ccc/tcaa024

Cole, W. M. (2005). Sovereignty relinquished? Explaining commitment to the international human rights covenants, 1966-1999. American Sociological Review, 70(3), 472-495. https://doi.org/10.1177/000312240507000306

Costa, R., \& Menichini, T. (2013). A multidimensional approach for CSR assessment: The importance of the stakeholder perception. Expert Systems with Applications, 40(1), 150-161. https://doi.org/10.1016/j.eswa.2012.07.028

Crain, S. P., Zhou, K., Yang, S.-H., \& Zha, H. (2012). Dimensionality reduction and topic modeling: From Latent Semantic Indexing to Latent Dirichlet Allocation and beyond. In C. C. Aggarwal \& C. Zhai (Eds.), Mining text data (pp. 129-161). Springer.

Currier, A., \& Cruz, J. M. (2020). The politics of pre-emption: Mobilisation against LGBT rights in Liberia. Social Movement Studies, 19(1), 82-96. https://doi.org/10.1080/14742837.2017.1319265

Davenport, C., \& Armstrong, D. A. (2004). Democracy and the violation of human rights: A statistical analysis from 1976 to 1996. American fournal of Political Science, 48(3), 538-554. https://doi.org/10.1111/j.0092-5853.2004.00086.x

Davis, K. (1960). Can business afford to ignore social responsibilities? California Management Review, 2(3), 70-76. https://doi.org/10.2307/41166246

Davis, K. (1973). The case for and against business assumption of social responsibilities. Academy of Management fournal, 16(2), 312-322. https://doi.org/10.2307/255331

DiMaggio, P. J., \& Powell, W. W. (1983). The iron cage revisited: Institutional isomorphism and collective rationality in organizational fields. American Sociological Review, 48(2), 147. https://doi.org/10.2307/2095101

Ding, D. K., Ferreira, C., \& Wongchoti, U. (2019). The geography of CSR. International Review of Economics \& Finance, 59, 265-288. https://doi.org/10.1016/j.iref.2018.09.003 
Doerfel, M. L., \& Barnett, G. A. (1999). A semantic network analysis of the International Communication Association. Human Communication Research, 25(4), 589-603. https://doi.org/10.1111/j.1468-2958.1999.tb00463.x

Doh, J. P., \& Guay, T. R. (2006). Corporate social responsibility, public policy, and NGO activism in Europe and the United States: An institutional-stakeholder perspective. Journal of Management Studies, 43(1), 47-73. https://doi.org/10.1111/j.1467-6486.2006.00582.x

Donaldson, T., \& Preston, L. E. (1995). The stakeholder theory of the corporation: Concepts, evidence, and implications. Academy of Management Review, 20(1), 65. https://doi.org/10.2307/258887

Donnelly, J. (1999). Human rights, democracy, and development. Human Rights Quarterly, 21(3), 608-632. https://doi.org/10.1353/hrq.1999.0039

Edwards, L. (2015). Power, diversity and public relations. Routledge.

Edwards, L., \& L’Etang, J. (2013). Invisible and visible identities and sexualities in public relations. In N. T. J. Tindall \& R. D. Waters (Eds.), Coming out of the closet: Exploring LGBT issues in strategic communication with theory and research (pp. 41-53). Peter Lang.

Epprecht, M. (2013). Sexuality and social justice in Africa: Rethinking homophobia and forging resistance. Zed Books.

Flores, A. R. (2019). Social acceptance of LGBT people in 174 countries. The Williams Institute. https://williamsinstitute.law.ucla.edu/wp-content/uploads/Global-Acceptance-IndexLGBT-Oct-2019.pdf

Formby, E. (2017). Exploring LGBT spaces and communities: Contrasting identities, belongings and wellbeing. Routledge.

Freeman, R. E. (1984). Strategic management: A stakeholder approach. Pitman.

García-Jiménez, L., Sánchez-Soriano, J. J., \& Prego-Nieto, M. (2021). The identity of LGBTQ communication research: From the Anglo-Saxon effervescence to the Spanish-speaking barrenness. International fournal of Communication, 15, 143-162. 
Githens, R. P. (2009). Capitalism, identity politics, and queerness converge: LGBT employee resource groups. New Horizons in Adult Education \& Human Resource Development, 23(3), 18-31. https://doi.org/10.1002/nha3.10347

Grimmer, J., \& Stewart, B. M. (2013). Text as data: The promise and pitfalls of automatic content analysis methods for political texts. Political Analysis, 21(3), 267-297. https://doi.org/10.1093/pan/mps028

Gross, L. (2005). The past and the future of gay, lesbian, bisexual, and transgender studies. Journal of Communication, 55(3), 508-528. https://doi.org/10.1111/j.1460-2466.2005.tb02683.x

Hebl, M., Cheng, S. K., \& Ng, L. C. (2020). Modern discrimination in organizations. Annual Review of Organizational Psychology and Organizational Behavior, 7(1), 257-282. https://doi.org/10.1146/annurev-orgpsych-012119-044948

Hon, L. C., \& Brunner, B. (2000). Diversity issues and public relations. Fournal of Public Relations Research, 12(4), 309-340. https://doi.org/10.1207/S1532754XJPRR1204_2

Human Rights Campaign. (2020). Corporate Equality Index (CEI) 2020. https://www.hrc.org/resources/corporate-equality-index

Jain, T., Aguilera, R. V., \& Jamali, D. (2017). Corporate stakeholder orientation in an emerging country context: A longitudinal cross industry analysis. Journal of Business Ethics, 143(4), 701-719. https://doi.org/10.1007/s10551-016-3074-1

Jenkins, C. (2016, July 31). Opponents target North Carolina transgender bathroom law. Reuters. https://www.reuters.com/article/us-usa-lgbt-north-carolina-feature-idUSKCN10B0F7

Johnson, H. L. (1971). Business in contemporary society: Framework and issues. Wadsworth. Kapur, M. (2020, February 28). Delhi's maiden LGBTQI job fair was only the first step towards workplace diversity. Quartz India. https:/qz.com/india/1808625/microsoft-uber-kpmg-attend-delhis-first-lgbtqi-job-fair/ 
Khan, F. R., \& Lund-Thomsen, P. (2011). CSR as imperialism: Towards a phenomenological approach to CSR in the developing world. Journal of Change Management, 11(1), 73-90. https://doi.org/10.1080/14697017.2011.548943

Labott, E., \& Farshbaf, N. (2013, December 24). U.S., Richard Branson slam Uganda's anti-gay bill. CNN. https://edition.cnn.com/2013/12/24/world/africa/uganda-anti-gay-bill/

Lammers, J. C., \& Barbour, J. B. (2006). An institutional theory of organizational communication. Communication Theory, 16(3), 356-377. https://doi.org/10.1111/j.1468-2885.2006.00274.x

Lattemann, C., Fetscherin, M., Alon, I., Li, S., \& Schneider, A.-M. (2009). CSR communication intensity in Chinese and Indian multinational companies. Corporate Governance: An International Review, 17(4), 426-442. https://doi.org/10.1111/j.1467-8683.2009.00758.x

Li, M. (2021). Influence for social good: Exploring the roles of influencer identity and comment section in Instagram-based LGBTQ-centric corporate social responsibility advertising. International fournal of Advertising. https://doi.org/10.1080/02650487.2021.1884399

Lucas, C., Nielsen, R. A., Roberts, M. E., Stewart, B. M., Storer, A., \& Tingley, D. (2015). Computer-assisted text analysis for comparative politics. Political Analysis, 23(2), 254-277. https://doi.org/10.1093/pan/mpu019

Maignan, I., \& Ralston, D. A. (2002). Corporate social responsibility in Europe and the U.S.: Insights from businesses' self-presentations. Journal of International Business Studies, 33(3), 497-514. https://doi.org/10.1057/palgrave.jibs.8491028

Marshall, M. G., \& Gurr, T. R. (2020). Polity5 project: Political regime characteristics and transitions, 1800-2018. Center for Systemic Peace. https://www.systemicpeace.org/polityproject.html

McDonald, J. (2015). Organizational communication meets queer theory: Theorizing relations of "difference" differently. Communication Theory, 25(3), 310-329. https://doi.org/10.1111/comt.12060 
Mendos, L. R. (2019). State-sponsored homophobia 2019. The International Lesbian, Gay, Bisexual, Trans and Intersex Association. https://ilga.org/state-sponsored-homophobia-report-2019

Michaelson, J. (2014, December 28). How Canadian oilmen pinkwash the keystone pipeline: How proponents of Keystone XL cynically exploit LGBT people. The Daily Beast. https://www.thedailybeast.com/how-canadian-oilmen-pinkwash-the-keystone-pipeline

Morsing, M., \& Schultz, M. (2006). Corporate social responsibility communication: Stakeholder information, response and involvement strategies. Business Ethics: A European Review, 15(4), 323-338. https://doi.org/10.1111/j.1467-8608.2006.00460.x

Mundy, D. E. (2013). The spiral of advocacy: How state-based LGBT advocacy organizations use ground-up public communication strategies in their campaigns for the "Equality Agenda”. Public Relations Review, 39(4), 387-390. https://doi.org/10.1016/j.pubrev.2013.07.021

Nölke, A.-I. (2018). Making diversity conform? An intersectional, longitudinal analysis of LGBT-specific mainstream media advertisements. fournal of Homosexuality, 65(2), 224-255. https://doi.org/10.1080/00918369.2017.1314163

NYU School of Law. (2019, June 27). Opening up the world: How multinational organizations can ascend the maturity curve on LGBT+ rights. https://www.nyu.edu/about/news-publications/news/2019/june/how-multinationalcorporations-can-advance-lgbt--rights-in-anti-.html

O'Connor, A., \& Gronewold, K. L. (2013). Black gold, green earth: An analysis of the petroleum industry’s CSR environmental sustainability discourse. Management Communication Quarterly, 27(2), 210-236. https://doi.org/10.1177/0893318912465189

O’Connor, A., \& Ihlen, Ø. (2018). Corporate social responsibility and rhetoric: Conceptualization, construction, and negotiation. In Ø. Ihlen \& R. L. Heath (Eds.), The handbook of organizational rhetoric and communication (pp. 401-416). Wiley-Blackwell. 
O’Connor, A., \& Shumate, M. (2010). An economic industry and institutional level of analysis of corporate social responsibility communication. Management Communication Quarterly, 24(4), 529-551. https://doi.org/10.1177/0893318909358747

Poushter, J., \& Kent, N. (2020, June 25). The global divide on homosexuality persists. Pew Research Center. https://www.pewresearch.org/global/2020/06/25/global-divide-onhomosexuality-persists/

Read, G. L., van Driel, I. I., \& Potter, R. F. (2018). Same-sex couples in advertisements: An investigation of the role of implicit attitudes on cognitive processing and evaluation. Journal of Advertising, 47(2), 182-197. https://doi.org/10.1080/00913367.2018.1452653

Roberts, M. E., Stewart, B. M., \& Tingley, D. (2019). Stm : An $R$ package for structural topic models. Journal of Statistical Software, 91(2). https://doi.org/10.18637/jss.v091.i02

Roberts, M. E., Stewart, B. M., Tingley, D., Lucas, C., Leder-Luis, J., Gadarian, S. K., Albertson, B., \& Rand, D. G. (2014). Structural topic models for open-ended survey responses. American Journal of Political Science, 58(4), 1064-1082. https://doi.org/10.1111/ajps.12103

Rodriguez, N. S. (2016). Communicating global inequalities: How LGBTI asylum-specific NGOs use social media as public relations. Public Relations Review, 42(2), 322-332. https://doi.org/10.1016/j.pubrev.2015.12.002

Schoeneborn, D., \& Trittin, H. (2013). Transcending transmission: Towards a constitutive perspective on CSR communication. Corporate Communications: An International fournal, 18(2), 193-211. https://doi.org/10.1108/13563281311319481

Scholtens, B., \& Dam, L. (2007). Cultural values and international differences in business ethics. Journal of Business Ethics, 75(3), 273-284. https://doi.org/10.1007/s10551-006-9252-9

Schulman, S. (2011, November 22). Israel and "pinkwashing”. The New York Times. https://www.nytimes.com/2011/11/23/opinion/pinkwashing-and-israels-use-of-gays-asa-messaging-tool.html 
Schultz, F., Kleinnijenhuis, J., Oegema, D., Utz, S., \& van Atteveldt, W. (2012). Strategic framing in the BP crisis: A semantic network analysis of associative frames. Public Relations Review, 38(1), 97-107. https://doi.org/10.1016/j.pubrev.2011.08.003

Scott, W. R. (1995). Institutions and organizations. SAGE Publications.

Serrano, M. A., Boguna, M., \& Vespignani, A. (2009). Extracting the multiscale backbone of complex weighted networks. Proceedings of the National Academy of Sciences, 106(16), 6483-6488. https://doi.org/10.1073/pnas.0808904106

Sha, B.-L., \& Ford, R. L. (2007). Redefining “requisite variety”: The challenge of multiple diversities for the future of public relations excellence. In E. L. Toth (Ed.), The future of excellence in public relations and communication management: Challenges for the next generation (pp. 383-397). Lawrence Erlbaum.

Shumate, M., \& O’Connor, A. (2010). Corporate reporting of cross-sector alliances: The portfolio of NGO partners communicated on corporate websites. Communication Monographs, 77(2), 207-230. https://doi.org/10.1080/03637751003758201

Skaaning, S.-E. (2019, December 19). The global state of democracy indices methodology: Conceptualization and measurement framework, version 3. International Institute for Democracy and Electoral Assistance. https://www.idea.int/gsodindices/sites/default/files/idea-gsodi-2019-methodology-v3.pdf

Surowiecki, J. (2016, April 18). Unlikely alliances: When North Carolina's legislators tried to limit L.G.B.T. rights, big business was their toughest opponent. The New Yorker. https: //www.newyorker.com/magazine/2016/04/25/the-corporate-fight-for-social-justice

Sweeney, L., \& Coughlan, J. (2008). Do different industries report corporate social responsibility differently? An investigation through the lens of stakeholder theory. Fournal of Marketing Communications, 14(2), 113-124. https://doi.org/10.1080/13527260701856657

The Associated Press. (2015, March 14). Ikea pulls magazine from Russia over same-sex values law. https://apnews.com/article/3ea377d08be64780b8b061c54064363a 
Tilcsik, A. (2011). Pride and prejudice: Employment discrimination against openly gay men in the United States. American fournal of Sociology, 117(2), 586-626. https://doi.org/10.1086/661653

Tindall, N. T. J., \& Waters, R. D. (2012). Coming out to tell our stories: Using queer theory to understand the career experiences of gay men in public relations. Fournal of Public Relations Research, 24(5), 451-475. https://doi.org/10.1080/1062726X.2012.723279

Tindall, N. T. J., \& Waters, R. D. (Eds.). (2013). Coming out of the closet: Exploring LGBT issues in strategic communication with theory and research. Peter Lang.

Toledano, M., \& Riches, M. (2014). Brand alliance and event management for social causes: Evidence from New Zealand. Public Relations Review, 40(5), 807-814. https://doi.org/10.1016/j.pubrev.2014.09.001

Tsai, W.-H. S. (2011). How minority consumers use targeted advertising as pathways to self-empowerment. Journal of Advertising, 40(3), 85-98. https://doi.org/10.2753/JOA0091-3367400307

van der Meer, T. G. (2016). Automated content analysis and crisis communication research. Public Relations Review, 42(5), 952-961. https://doi.org/10.1016/j.pubrev.2016.09.001 van der Meer, T. G., \& Jonkman, J. G. (2021). Politicization of corporations and their environment: Corporations' social license to operate in a polarized and mediatized society. Public Relations Review, 47(1), 101988. https://doi.org/10.1016/j.pubrev.2020.101988

van Atteveldt, W., \& Peng, T.-Q. (2018). When communication meets computation: Opportunities, challenges, and pitfalls in computational communication science. Communication Methods and Measures, 12(2-3), 81-92. https://doi.org/10.1080/19312458.2018.1458084 van Marrewijk, M. (2003). Concepts and definitions of CSR and corporate sustainability: Between agency and communion. Journal of Business Ethics, 44(2), 95-105. https://doi.org/10.1023/A:1023331212247 
Wanderley, L. S. O., Lucian, R., Farache, F., \& de Sousa Filho, J. M. (2008). CSR information disclosure on the web: A context-based approach analysing the influence of country of origin and industry sector. Fournal of Business Ethics, 82(2), 369-378. https://doi.org/10.1007/s10551-008-9892-z

Wang, H., \& Qian, C. (2011). Corporate philanthropy and corporate financial performance: The roles of stakeholder response and political access. Academy of Management fournal, 54(6), 1159-1181. https://doi.org/10.5465/amj.2009.0548

Wettstein, F., \& Baur, D. (2016). "Why should we care about marriage equality?”: Political advocacy as a part of corporate responsibility. Journal of Business Ethics, 138(2), 199-213. https://doi.org/10.1007/s10551-015-2631-3

Xu, S., \& Zhou, A. (2020). Hashtag homophily in twitter network: Examining a controversial cause-related marketing campaign. Computers in Human Behavior, 102, 87-96. https://doi.org/10.1016/j.chb.2019.08.006

Yang, A., \& Liu, W. (2018). Corporate environmental responsibility and global online cross-sector alliance network: A cross-national study. Environmental Communication, 12(1), 99-114. https://doi.org/10.1080/17524032.2016.1249900

Yang, A., Liu, W., \& Wang, R. (2020). Cross-sector alliances in the global refugee crisis: An institutional theory approach. Business Ethics: A European Review. https://doi.org/10.1111/beer.12288

Yang, A., \& Veil, S. R. (2017). Nationalism versus animal rights: A semantic network analysis of value advocacy in corporate crisis. International fournal of Business Communication, 54(4), 408-430. https://doi.org/10.1177/2329488415572781

Zéghal, D., \& Maaloul, A. (2010). Analysing value added as an indicator of intellectual capital and its consequences on company performance. Journal of Intellectual Capital, 11(1), 39-60. https://doi.org/10.1108/14691931011013325 
Zhou, A. (2019). Bring publics back into networked public relations research: A dual-projection approach for network ecology. Public Relations Review, 45(4), 101772. https://doi.org/10.1016/j.pubrev.2019.03.004 
Table 1

NGO Guidelines on Corporate LGBTQ Advocacy

\begin{tabular}{|c|c|c|c|}
\hline Level of Investment & Keywords & NGO Guidelines & In LGBTQ CSR Discourse \\
\hline \multirow[t]{8}{*}{ Low } & Discrimination & $\begin{array}{l}\text { Prohibit discrimination and harassment } \\
\text { based on sexual orientation and gender identity }\end{array}$ & $\checkmark$ \\
\hline & Training & $\begin{array}{l}\text { Integrate LGBTQ topics in internal training } \\
\text { for workplace awareness }\end{array}$ & $\sqrt{ }$ \\
\hline & Culture & $\begin{array}{l}\text { Foster an organizational culture } \\
\text { that is inclusive of LGBTQ individuals }\end{array}$ & $\sqrt{ }$ \\
\hline & Metrics & $\begin{array}{l}\text { Include LGBTQ diversity metrics } \\
\text { in leadership performance measures }\end{array}$ & - \\
\hline & Data & $\begin{array}{l}\text { Monitor anonymous employee data } \\
\text { on sexual orientation and gender identity }\end{array}$ & - \\
\hline & Supplier & $\begin{array}{l}\text { Enforce non-discrimination policies on } \\
\text { suppliers during procurement processes }\end{array}$ & $\checkmark$ \\
\hline & Networks & $\begin{array}{l}\text { Maintain Employee Resource Groups } \\
\text { for LGBTQ individuals }\end{array}$ & $\checkmark$ \\
\hline & Benefit & $\begin{array}{l}\text { Ensure equivalency in health benefits } \\
\text { for same- and different-sex couples }\end{array}$ & $\checkmark$ \\
\hline High & Outreach & $\begin{array}{l}\text { Demonstrate philanthropic support } \\
\text { for LGBTQ organizations and events }\end{array}$ & - \\
\hline
\end{tabular}


Table 2

CSR Discourse on LGBTQ Advocacy: Structural Topic Modeling

\begin{tabular}{|c|c|c|c|}
\hline Level of Investment & Topics & Relevant Words & Topical proportion \\
\hline \multirow[t]{5}{*}{ Low } & Discrimination & $\begin{array}{l}\text { High Probability: Employee, Discrimination, Gender, Sexual, Policy, Age, Disable, Orientation } \\
\text { High Exclusivity: Discrimination, Religion, Ethics, Origin, Code, Complaint, Race, Labor }\end{array}$ & $20.1 \%$ \\
\hline & Training & $\begin{array}{l}\text { High Probability: Human, Rights, Respect, Promote, Training, Activity, Sexual, Harass } \\
\text { High Exclusivity: Human, Rights, Seminar, Awareness, Lecture, Harass, Consult, Violate }\end{array}$ & $14.2 \%$ \\
\hline & Culture & $\begin{array}{l}\text { High Probability: Inclusive, Diverse, Workplace, Equal, Culture, Business } \\
\text { High Exclusivity: Colleague, Everyone, Inclusive, Workplace, Progress, Change }\end{array}$ & $18.0 \%$ \\
\hline & Supplier & $\begin{array}{l}\text { High Probability: Supplier, Diverse, Business, Program, Develop, Enterprise } \\
\text { High Exclusivity: Supplier, Spend, Procurement, Council, Enterprise, Own, Chain }\end{array}$ & $10.4 \%$ \\
\hline & Networks & $\begin{array}{l}\text { High Probability: Diverse, Employee, Network, Resource, Group, Association, Program } \\
\text { High Exclusivity: Association, Fund, Latino, Hispanic, Black. Chapter, Ally, Asian }\end{array}$ & $14.4 \%$ \\
\hline High & Benefit & $\begin{array}{l}\text { High Probability: Employee, Health, Equal, Benefit, Include, Support, Provide, Commit } \\
\text { High Exclusivity: Health, Healthcare, Medical, Benefit, Patient, Children, Family, Care }\end{array}$ & $10.7 \%$ \\
\hline
\end{tabular}

Note: All stemmed unigrams have been rehydrated back to their most frequent forms. 


\section{Table 3}

Hypotheses and Results

\begin{tabular}{|c|c|c|c|}
\hline Outcomes & Variables & Hypotheses & Results \\
\hline \multirow[t]{6}{*}{$\begin{array}{l}\text { H1. Communicate CSR } \\
\text { Efforts on LGBTQ Issues }\end{array}$} & H1a. Continents & $\begin{array}{l}\text { Corporations in North America and Europe are more likely to } \\
\text { communicate LGBTQ advocacy in CSR reporting than those in Asia. }\end{array}$ & Supported \\
\hline & H1b1. Politics & $\begin{array}{l}\text { Corporations headquartered in countries with higher levels of democracy } \\
\text { are more likely to communicate LGBTQ advocacy in CSR reporting. }\end{array}$ & Supported \\
\hline & H1b2. Politics & $\begin{array}{l}\text { Corporations headquartered in countries with higher levels of civil liberty } \\
\text { are more likely to communicate LGBTQ advocacy in CSR reporting. }\end{array}$ & Supported \\
\hline & H1b3. Politics & $\begin{array}{l}\text { Corporations headquartered in countries with higher levels of legal protections } \\
\text { are more likely to communicate LGBTQ advocacy in CSR reporting. }\end{array}$ & Supported \\
\hline & H1c: Industries & $\begin{array}{l}\text { Corporations in the traditional industry are less likely to communicate LGBTQ } \\
\text { advocacy in CSR reporting than those in the services and high tech industries. }\end{array}$ & Supported \\
\hline & H1d: Expectations & $\begin{array}{l}\text { Corporations headquartered in countries with higher levels of LGBTQ } \\
\text { acceptance are more likely to communicate LGBTQ advocacy in CSR reporting. }\end{array}$ & Supported \\
\hline \multirow{7}{*}{$\begin{array}{l}\text { H2. Emphasize High- } \\
\text { Investment Topics }\end{array}$} & H2a Continents & Corporations in North America and Europe will give less emphases to & Partially \\
\hline & 112a. Comthemts & low-investment LGBTQ efforts in CSR reporting than those in Asia. & Supported \\
\hline & H2b1. Politics & $\begin{array}{l}\text { Corporations headquartered in countries with higher levels of democracy } \\
\text { will give less emphasis to low-investment LGBTQ efforts in CSR reporting. }\end{array}$ & Supported \\
\hline & H2b2. Politics & $\begin{array}{l}\text { Corporations headquartered in countries with higher levels of civil liberty } \\
\text { will give less emphasis to low-investment LGBTQ efforts in CSR reporting }\end{array}$ & Supported \\
\hline & H2b3. Politics & $\begin{array}{l}\text { Corporations headquartered in countries with higher levels of legal protections } \\
\text { will give less emphasis to low-investment LGBTQ efforts in CSR reporting. }\end{array}$ & Not Supported \\
\hline & H2c: Industries & $\begin{array}{l}\text { Corporations in the traditional industry will give more emphasis } \\
\text { to low-investment LGBTQ efforts in CSR reporting. }\end{array}$ & Not Supported \\
\hline & H2d: Expectations & $\begin{array}{l}\text { Corporations headquartered in countries with higher levels of LGBTQ acceptance } \\
\text { will give less emphasis to low-investment LGBTQ efforts in CSR reporting. }\end{array}$ & Supported \\
\hline
\end{tabular}

will give less emphasis to low-investment LGBTQ efforts in CSR reporting. 


\section{Table 4}

Regressing Whether CSR Report Mentions LGBTQ Issues on Corporate Variables

\begin{tabular}{|c|c|c|c|c|c|c|}
\hline & \multicolumn{6}{|c|}{ Dependent Variable: CSR Report Mentions LGBTQ Issues } \\
\hline & H1a & H1b1 & $\mathrm{H} 1 \mathrm{~b} 2$ & $\mathrm{H} 1 \mathrm{~b} 3$ & $\mathrm{H} 1 \mathrm{c}$ & H1d \\
\hline Oceania & $\begin{array}{c}16.041 \\
(550.089)\end{array}$ & & & & & \\
\hline Europe & $\begin{array}{l}1.135^{* * *} \\
(0.247)\end{array}$ & & & & & \\
\hline North America & $\begin{array}{l}1.353^{\star \star *} \\
(0.271)\end{array}$ & & & & & \\
\hline South America & $\begin{array}{c}2.084 \\
(1.109)\end{array}$ & & & & & \\
\hline Polity Democracy Score & & $\begin{array}{l}0.173^{\star \star *} \\
(0.025)\end{array}$ & & & & \\
\hline Civil Liberty Index & & & $\begin{array}{l}5.253^{\text {**t }} \\
(0.713)\end{array}$ & & & \\
\hline Legal Protection & & & & $\begin{array}{l}0.468^{* * *} \\
(0.087)\end{array}$ & & \\
\hline Services Industry & & & & & $\begin{array}{l}0.461^{*} \\
(0.221)\end{array}$ & \\
\hline High Tech Industry & & & & & $\begin{array}{l}1.286^{* *} \\
(0.401)\end{array}$ & \\
\hline Stakeholder Expectation & & & & & & $\begin{array}{l}0.552^{\star * *} \\
(0.074)\end{array}$ \\
\hline Observations & 406 & 406 & 405 & 406 & 406 & 405 \\
\hline $\mathrm{R}^{2}$ & 0.100 & 0.174 & 0.196 & 0.076 & 0.029 & 0.150 \\
\hline Adjusted $\mathrm{R}^{2}$ & 0.091 & 0.172 & 0.194 & 0.074 & 0.024 & 0.148 \\
\hline Residual Std. Error & $0.471(\mathrm{df}=401)$ & $0.450(\mathrm{df}=404)$ & $0.443(\mathrm{df}=403)$ & $0.475(\mathrm{df}=404)$ & $0.488(\mathrm{df}=403)$ & $0.456(\mathrm{df}=403)$ \\
\hline F Statistic & $11.119^{\star \star \star}(\mathrm{df}=4 ; 401)$ & $84.951^{\star \star *}(\mathrm{df}=1 ; 404)$ & $97.943^{\star \star \star}(\mathrm{df}=1 ; 403)$ & $33.182^{* \star *}(\mathrm{df}=1 ; 404)$ & $6.054^{\star * *}(\mathrm{df}=2 ; 403)$ & $71.088^{* \star \star *}(\mathrm{df}=1 ; 403)$ \\
\hline
\end{tabular}


Table 5

Regressing Topical Proportion of Anti-Discrimination Policy on Corporate Variables

\begin{tabular}{|c|c|c|c|c|c|c|}
\hline & \multicolumn{6}{|c|}{ Dependent Variable: Proportion Devoted to The Anti-Discrimination Topic } \\
\hline & $\mathrm{H} 2 \mathrm{a}$ & $\mathrm{H} 2 \mathrm{~b} 1$ & $\mathrm{H} 2 \mathrm{~b} 2$ & $\mathrm{H} 2 \mathrm{~b} 3$ & $\mathrm{H} 2 \mathrm{c}$ & $\mathrm{H} 2 \mathrm{~d}$ \\
\hline Oceania & $\begin{array}{l}-0.271^{*} \\
(0.116)\end{array}$ & & & & & \\
\hline Europe & $\begin{array}{l}-0.064 \\
(0.049)\end{array}$ & & & & & \\
\hline North America & $\begin{array}{c}-0.224^{* * *} \\
(0.051)\end{array}$ & & & & & \\
\hline South America & $\begin{array}{l}0.271^{*} \\
(0.135)\end{array}$ & & & & & \\
\hline Polity Democracy Score & & $\begin{array}{l}-0.015^{*} \\
(0.007)\end{array}$ & & & & \\
\hline Civil Liberty Index & & & $\begin{array}{l}-0.752^{2+* *} \\
(0.183)\end{array}$ & & & \\
\hline Legal Protection & & & & $\begin{array}{l}0.051^{* *} \\
(0.019)\end{array}$ & & \\
\hline Services Industry & & & & & $\begin{array}{l}-0.032 \\
(0.047)\end{array}$ & \\
\hline High Tech Industry & & & & & $\begin{array}{l}-0.050 \\
(0.066)\end{array}$ & \\
\hline Stakeholder Expectation & & & & & & $\begin{array}{c}-0.050^{* *} \\
(0.017) \\
\end{array}$ \\
\hline Observations & 236 & 236 & 236 & 236 & 236 & 236 \\
\hline $\mathrm{R}^{2}$ & 0.125 & 0.021 & 0.067 & 0.029 & 0.003 & 0.037 \\
\hline Adjusted $\mathrm{R}^{2}$ & 0.110 & 0.017 & 0.063 & 0.025 & -0.006 & 0.033 \\
\hline Residual Std. Error & $0.290(\mathrm{df}=231)$ & $0.304(\mathrm{df}=234)$ & $0.297(\mathrm{df}=234)$ & $0.303(\mathrm{df}=234)$ & $0.308(\mathrm{df}=233)$ & $0.302(\mathrm{df}=234)$ \\
\hline F Statistic & $8.227^{* * *}(\mathrm{df}=4 ; 231)$ & $5.140^{*}(\mathrm{df}=1 ; 234)$ & $16.921^{* * *}(\mathrm{df}=1 ; 234)$ & $6.934^{* *}(\mathrm{df}=1 ; 234)$ & $0.355(\mathrm{df}=2 ; 233)$ & $8.956^{* *}(\mathrm{df}=1 ; 234)$ \\
\hline
\end{tabular}




\section{Figure 1}

CSR Discourse on LGBTQ Advocacy: Semantic Network

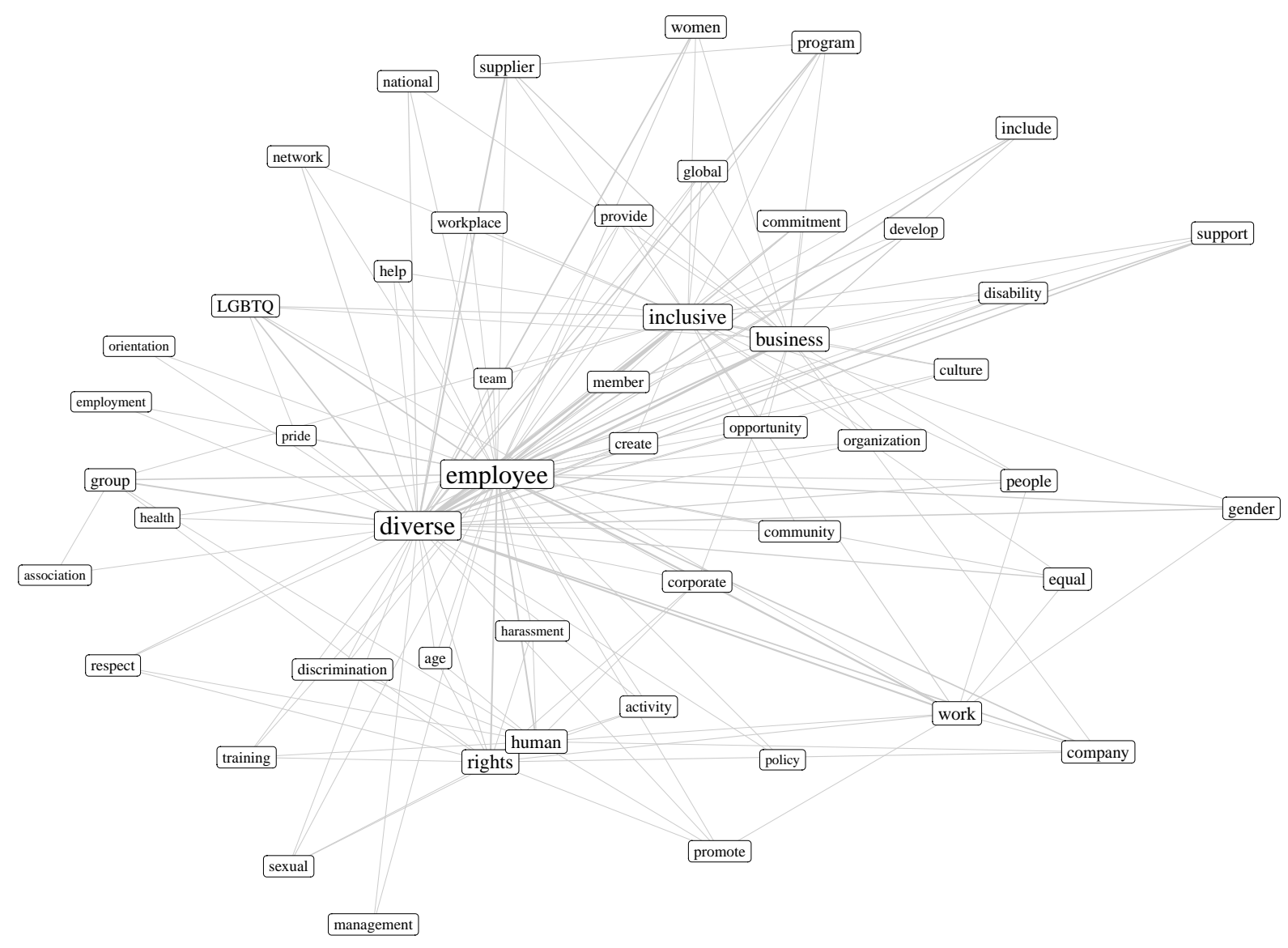

Note: The tie width corresponds to the number of documents $(N=236)$ that mentioned the two words. The label size corresponds to the word's weight (weighted degree centrality). The original semantic network before filtering contains 2,511 nodes and 1,222,949 edges. Multiple rounds of backbone extraction (Serrano et al., 2009) and thresholding based on degree centralities were performed to visualize the top 50 words in the semantic network. All stemmed unigrams have been rehydrated back to their most frequent forms for visualization. 


\title{
Online Appendix
}

\author{
Communicating Corporate LGBTQ Advocacy: \\ A Computational Comparison of the Global CSR Discourse
}

\section{Variables and Descriptive Results}

Fortune assigned its 2018 Global 500 companies into 55 industries, which was excessive for the current research. Therefore, the Industry Classification Benchmark (ICB) and the Standard Industrial Classification (SIC) were consulted along with the three-way classification scheme developed by Zéghal and Maaloul (n.d.) to classify the examined companies to three main categories: traditional (such as mining, utilities, and petroleum refining), high tech (such as softwares, semiconductors, and telecommunications), and services (such as financials, apparel, and retailers), with details shown in Table 1.

As the main text detailed, among the 2018 Fortune Global 500 companies, 406 companies provided downloadable PDF files for their corporate social responsibility (CSR) reports. In total, 236 companies' CSR reports mentioned lesbian, gay, bisexual, transgender, and queer (LGBTQ) issues. The data set also contains two other covariates: rank, the company's 2018 Fortune Global ranking; and continent, as suggested by the company's headquarter. Table 2 and Table 3 summarize the data set.

Regressing the dummy variable of whether a company publishes CSR reports on these covariates using logistic regression, Table 4 reveal that companies in Oceana and Europe and in technology and services industries are more likely to publish CSR reports, compared to companies in Asia and in the traditional industry.

\section{Corpus Construction and Model Selection}

Data cleaning and preparation are completed with quanteda and tidyverse packages in R environment and detailed below.

After the corpus - consisting of 236 documents - was constructed, the document-feature matrix was built with English stopwords, punctuations, numbers, and symbols removed and each word stemmed. The document-feature matrix was then reduced by frequency threshold-based feature selection, which only retained features that existed in at least two documents. It is assumed that features that only existed in one document - features that did not have any linguistic association with other companies' text - did not meaningfully contribute to the overall global CSR discourse. Additionally, features that only existed in one document are oftentimes linguistic irregularities that need to be removed in the first place.

Researchers then examined top features and constructed custom stopwords and thesauri

for further document-feature matrix reduction. For this corpus, the following features were deemed as custom stopwords: can, use, first, second, third, also, year, best, across, us, one, within, 
Table 1: Industry Classification of Fortune Global 500 Companies

\begin{tabular}{|c|c|c|c|c|}
\hline Three-Way Classification & ICB Classification & Fortune Global 500 Industries & $N$ & Example \\
\hline \multirow[t]{20}{*}{ Traditional } & \multirow[t]{5}{*}{ Basic Materials } & Building Materials, Glass & 4 & Saint-Gobain \\
\hline & & Chemicals & 7 & DowDuPont \\
\hline & & Metals & 15 & POSCO \\
\hline & & Mining, Crude-Oil Production & 21 & ConocoPhillips \\
\hline & & Textiles & 2 & Hengli Group \\
\hline & \multirow[t]{3}{*}{ Energy } & Energy & 9 & E.ON \\
\hline & & Petroleum Refining & 31 & Exxon Mobil \\
\hline & & Pipelines & 4 & Enbridge \\
\hline & \multirow[t]{10}{*}{ Industrials } & Aerospace \& Defense & 14 & Boeing \\
\hline & & Construction and Farm Machinery & 2 & Caterpillar \\
\hline & & Engineering \& Construction & 11 & China Railway Construction \\
\hline & & Human Resources \& Employment Services & 2 & Adecco Group \\
\hline & & Industrial Machinery & 7 & Siemens \\
\hline & & Mail, Package, and Freight Delivery & 7 & UPS \\
\hline & & Oil \& Gas Equipment, Services & 1 & Schlumberger \\
\hline & & Railroads & 3 & East Japan Railway \\
\hline & & Shipping & 4 & China State Shipbuilding \\
\hline & & Wholesalers: Electronics and Office Equipment & 2 & Arrow Electronics \\
\hline & Real Estate & Real Estate & 5 & Evergrande Real Estate Group \\
\hline & Utilities & Utilities & 18 & Exelon \\
\hline \multirow[t]{7}{*}{ High Tech } & \multirow[t]{4}{*}{ Technology } & Computer Software & 3 & Oracle \\
\hline & & Computers, Office Equipment & 9 & Apple \\
\hline & & Information Technology Services & 5 & IBM \\
\hline & & Semiconductors and Other Electronic Components & 4 & Intel \\
\hline & \multirow[t]{3}{*}{ Telecommunications } & Internet Services and Retailing & 6 & Facebook \\
\hline & & Network and Other Communications Equipment & 4 & Cisco Systems \\
\hline & & Telecommunications & 17 & AT\&T \\
\hline \multirow[t]{28}{*}{ Services } & \multirow[t]{7}{*}{ Consumer Discretionary } & Airlines & 7 & Delta Air Lines \\
\hline & & Apparel & 3 & Nike \\
\hline & & Electronics, Electrical Equip. & 15 & Electronics \\
\hline & & Entertainment & 3 & Walt Disney \\
\hline & & Household and Personal Products & 3 & Unilever \\
\hline & & Motor Vehicles \& Parts & 34 & BMW \\
\hline & & Specialty Retailers & 9 & Home Depot \\
\hline & \multirow[t]{8}{*}{ Consumer Staples } & Beverages & 4 & Coca-Cola \\
\hline & & Food \& Drug Stores & 20 & Walgreens \\
\hline & & Food Consumer Products & 5 & Nestlé \\
\hline & & Food Production & 7 & Tyson Foods \\
\hline & & Food Services & 1 & Compass Group \\
\hline & & General Merchandisers & 4 & Walmart \\
\hline & & Tobacco & 2 & Philip Morris International \\
\hline & & Wholesalers: Food and Grocery & 3 & Sysco \\
\hline & \multirow[t]{7}{*}{ Financials } & Banks: Commercial and Savings & 51 & Citigroup \\
\hline & & Diversified Financials & 9 & Fannie Mae \\
\hline & & Insurance: Life, Health (Mutual) & 10 & TIAA \\
\hline & & Insurance: Life, Health (Stock) & 24 & Prudential Financial \\
\hline & & Insurance: Property and Casualty (Mutual) & 2 & Nationwide \\
\hline & & Insurance: Property and Casualty (Stock) & 16 & Allstate \\
\hline & & Trading & 20 & Mitsui \\
\hline & \multirow[t]{6}{*}{ Health Care } & Health Care: Insurance and Managed Care & 6 & Aetna \\
\hline & & Health Care: Medical Facilities & 2 & HCA Holdings \\
\hline & & Health Care: Pharmacy and Other Services & 2 & CVS Health \\
\hline & & Medical Products and Equipment & 3 & Royal Philips \\
\hline & & Pharmaceuticals & 13 & Merck \\
\hline & & Wholesalers: Health Care & 5 & McKesson \\
\hline
\end{tabular}


Table 2: Dataset Description by Continent

\begin{tabular}{llll}
\hline & Fortune Global 500 & CSR Reports Available & LGBTQ Issues Mentioned \\
\hline North America & 143 & 109 & 77 \\
Europe & 141 & 138 & 91 \\
Asia & 202 & 146 & 56 \\
Oceania & 7 & 7 & 7 \\
South America & 7 & 6 & 5 \\
Total & 500 & 406 & 236 \\
\hline
\end{tabular}

Table 3: Dataset Description by Industry

\begin{tabular}{llll}
\hline & Fortune Global 500 & CSR Reports Available & LGBTQ Issues Mentioned \\
\hline Traditional & 169 & 128 & 62 \\
High Tech & 48 & 44 & 34 \\
Services & 283 & 234 & 140 \\
Total & 500 & 406 & 236 \\
\hline
\end{tabular}

Table 4: Regressing Whether Corporation Publishes CSR Report on Variables

\begin{tabular}{|c|c|c|}
\hline & \multicolumn{2}{|c|}{ Dependent Variable: CSR Report Published } \\
\hline Oceania & $\begin{array}{c}14.608 \\
(550.089)\end{array}$ & \\
\hline Europe & $\begin{array}{l}2.870^{* * *} \\
(0.604)\end{array}$ & \\
\hline North America & $\begin{array}{c}0.207 \\
(0.252)\end{array}$ & \\
\hline South America & $\begin{array}{c}0.834 \\
(1.092)\end{array}$ & \\
\hline Services Industry & & $\begin{array}{c}0.069^{*} \\
(0.038)\end{array}$ \\
\hline High Tech Industry & & $\begin{array}{l}0.159^{* *} \\
(0.064)\end{array}$ \\
\hline Observations & 500 & 500 \\
\hline $\mathrm{R}^{2}$ & 0.080 & 0.014 \\
\hline Adjusted $\mathrm{R}^{2}$ & 0.073 & 0.010 \\
\hline Residual Std. Error & $0.377(\mathrm{df}=495)$ & $0.389(\mathrm{df}=497)$ \\
\hline F Statistic & $10.832^{* * *}(\mathrm{df}=4 ; 495)$ & $3.607^{* *}(\mathrm{df}=2 ; 497)$ \\
\hline
\end{tabular}


Figure 1: Diagnostic Values by Number of Topics
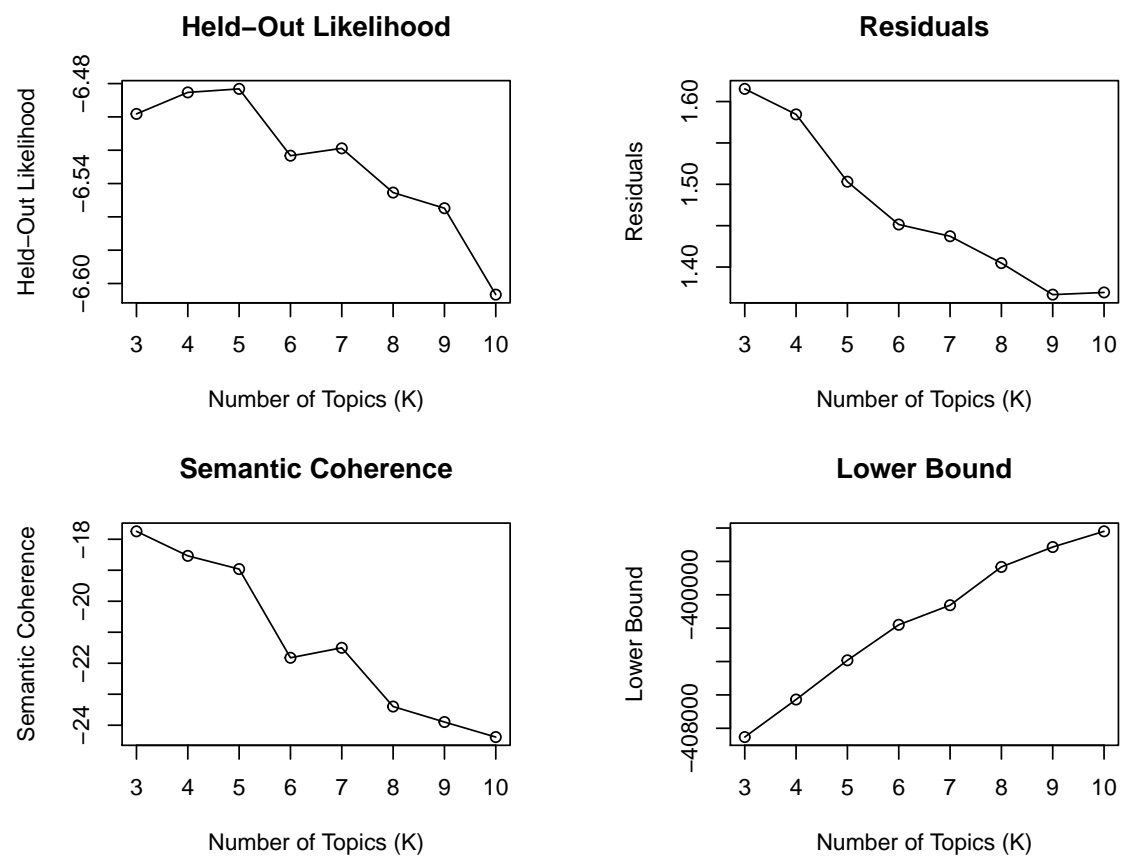

u., sinc, uk, two, among, day, around, $d$, includ, addit, continu, part, person, well, may, make, made, citi, three, found, without, five, per, ag, de, p, 25th, 10th, 13th, new. The feature lgbtq was used as the thesaurus of $\lg b t q, \lg b t, \lg b t i$, and $\lg b t a$, and the feature sexual was used as the thesaurus of sex.

The structural topic model was implemented with two covariates - continent, and industry - as topic prevalence covariates. Diagnosis values for held-out likelihood, residuals, and semantic coherence were shown in Figure 1. To achieve topical diversity and relatively high heldout likelihood and semantic coherence, the appropriate number of topics is suspected to be six, seven, or eight. However, the model diagnosis is at best a relative criterion, with the better criterion being qualitative judgement of the actual topic modeling quality, considering both topical coherence and exclusivity. Researchers find the 7-topic model to provide most useful insights into the latent topics in the global LGBTQ CSR discourse, comparing it to the discourse constructed by non-governmental agencies. To provide more data transparency, top words and topic proportions from the 6-topic model and the 8-topic model are shown as Figure 2 for comparison.

The raw data behind the 7-topic model is shown in Table 5 and Figure 3. Table 5 shows two different types of words that constituted a given topic similar to the main text, with High Probability indicating words that is mostly associated with the said topic and High Exclusivity indicating words that distinguish the said topic from other topics. Figure 3 shows the word cloud of the 7-topic model, with keywords highlighted in red.

\section{Comparison}

As mentioned in the main text, regressing topic proportion on variables might underestimate standard deviations of some covariates' effects. Here, we use the native estimateEffect 
Figure 2: Structural Topic Modeling Results for 6, 7, and 8 Topics

\section{LGBTQ CSR 6 Topics}

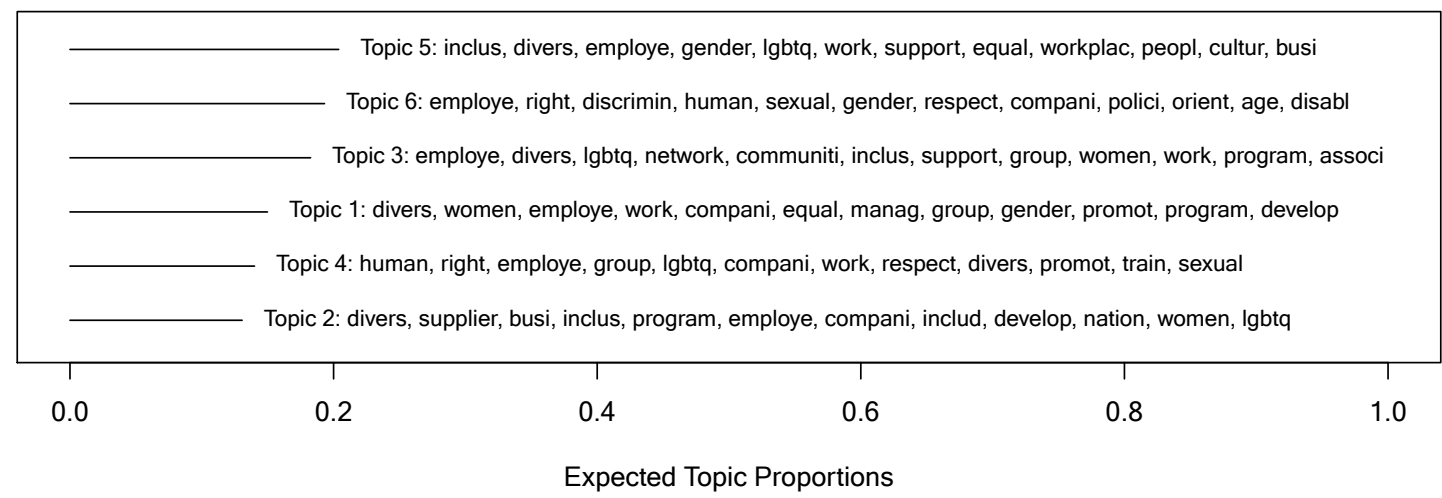

\section{LGBTQ CSR 7 Topics}

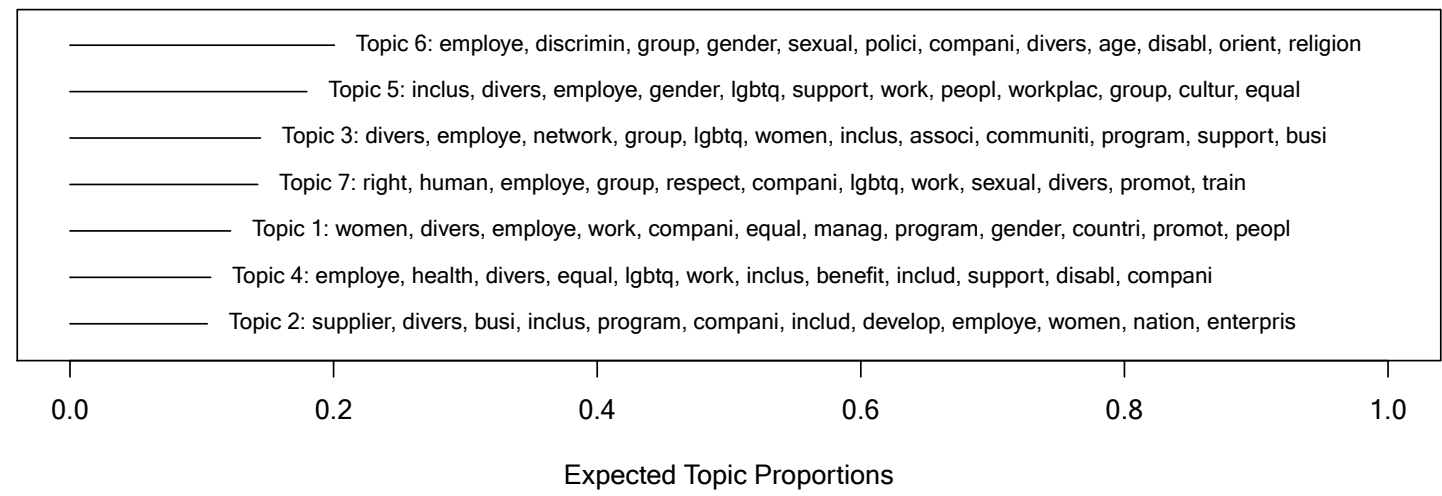

\section{LGBTQ CSR 8 Topics}

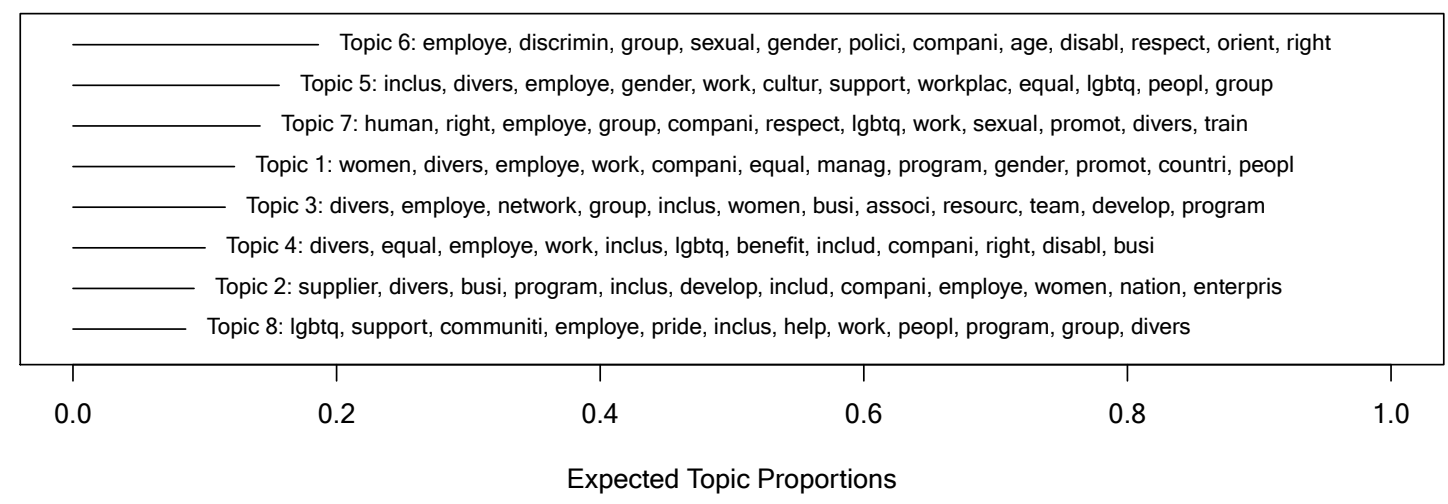


Figure 3: Word Clouds for 7-Topic Result

A: Topic 1 -Supplier

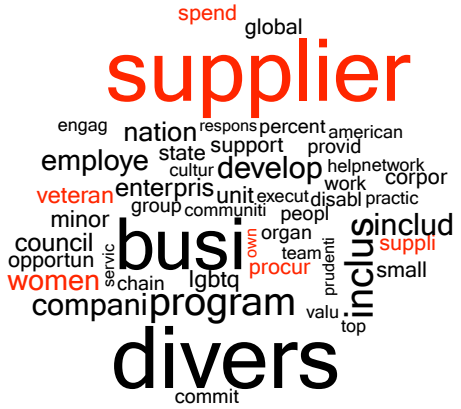

C: Topic 3 -Benefit

health program women equal communiti benefit right commit

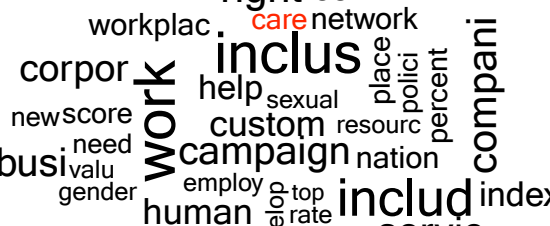

. human $\frac{}{d}$ rate

divers 응 organ famili

healthcarpeopl providchildrendisabl employelgbtq support

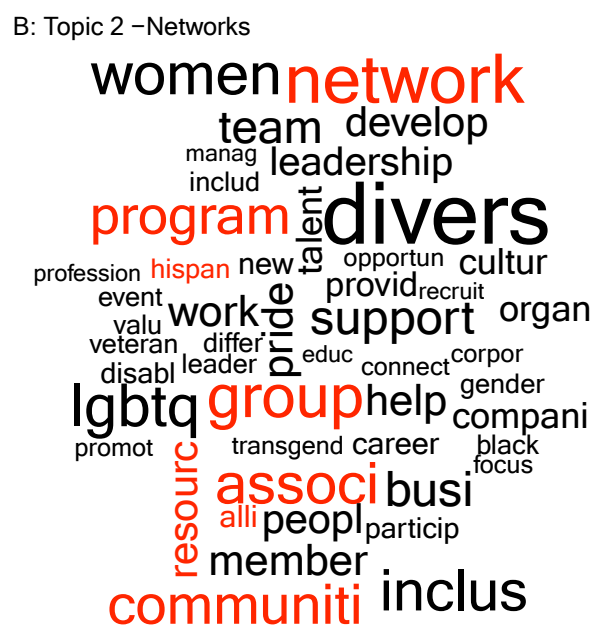

D: Topic 4 -Culture

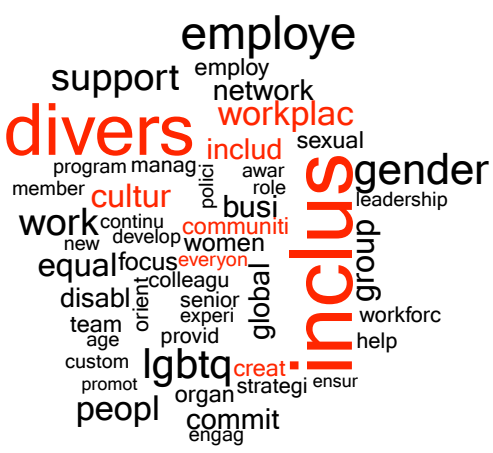

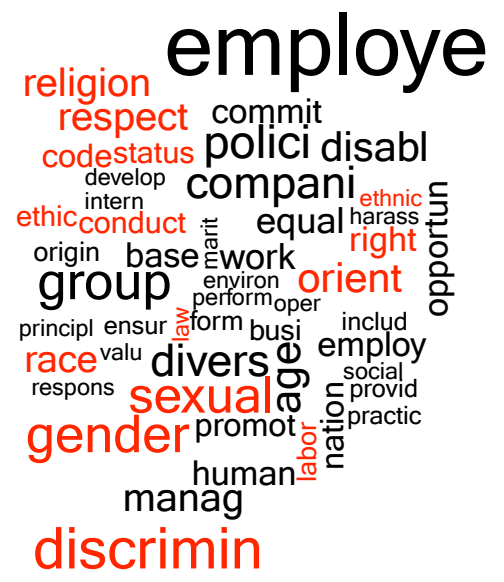


Table 5: Raw 7-Topic STM Result Before Labeling

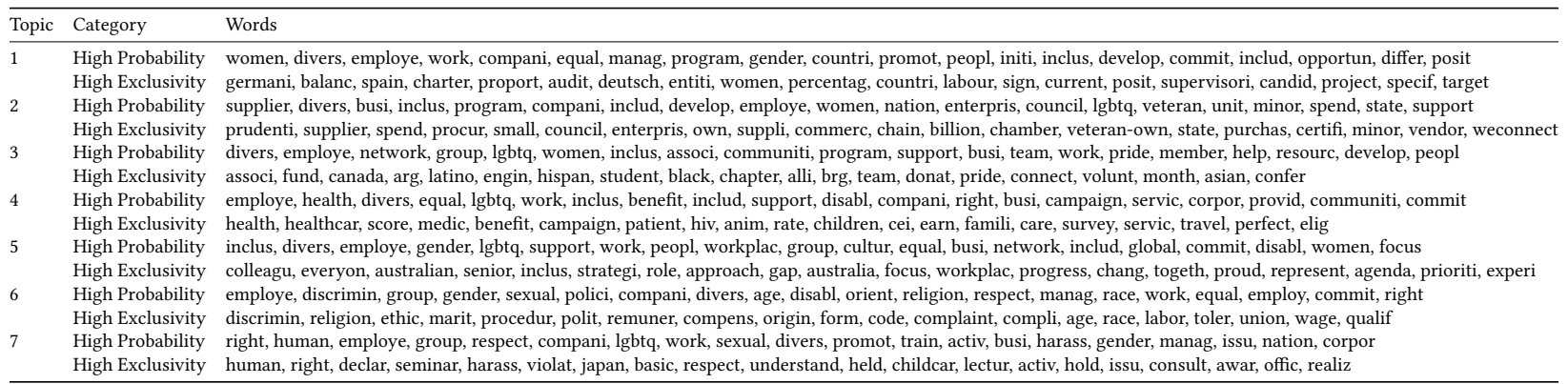

and plot.estimateEffect functions to provide a robust check on our regression results.

Shown in Figure 4 Panel A and B, two categorical variables' effects stay significant, as companies in Asia emphasize more on their legal responsibilities than those based in North America (North America, $b=-0.22, p<.001$ ), while there is no significant difference between Europe and Asia (Europe, $b=-.09, p=.14$ ). Panel $\mathrm{C}$ examines the effect of democracy levels on topic proportion, which according to our linear regression model is significant. However, in this robustness check, its effect is only marginally significant $(b=-.02, p=.06)$. The effect of state-level legal protection also becomes marginally significant $(b=.04, p=.07)$, shown in Panel E. Findings on the remaining two variables continue to be valid when we consider the STM model's measurement uncertainty, as civil liberty level $(b=-.73, p<.001)$ and stakeholder expectation $(b=-.05, p<.01)$ decrease the topic proportion for anti-discrimination policy.

\section{References}

Zéghal, D., \& Maaloul, A. (n.d.). Analysing value added as an indicator of intellectual capital and its consequences on company performance., 11(1), 39-60. doi: 10.1108/14691931011013325 
Figure 4: Effects of Covariates on Topic Proportion of Anti-Discrimination Policy
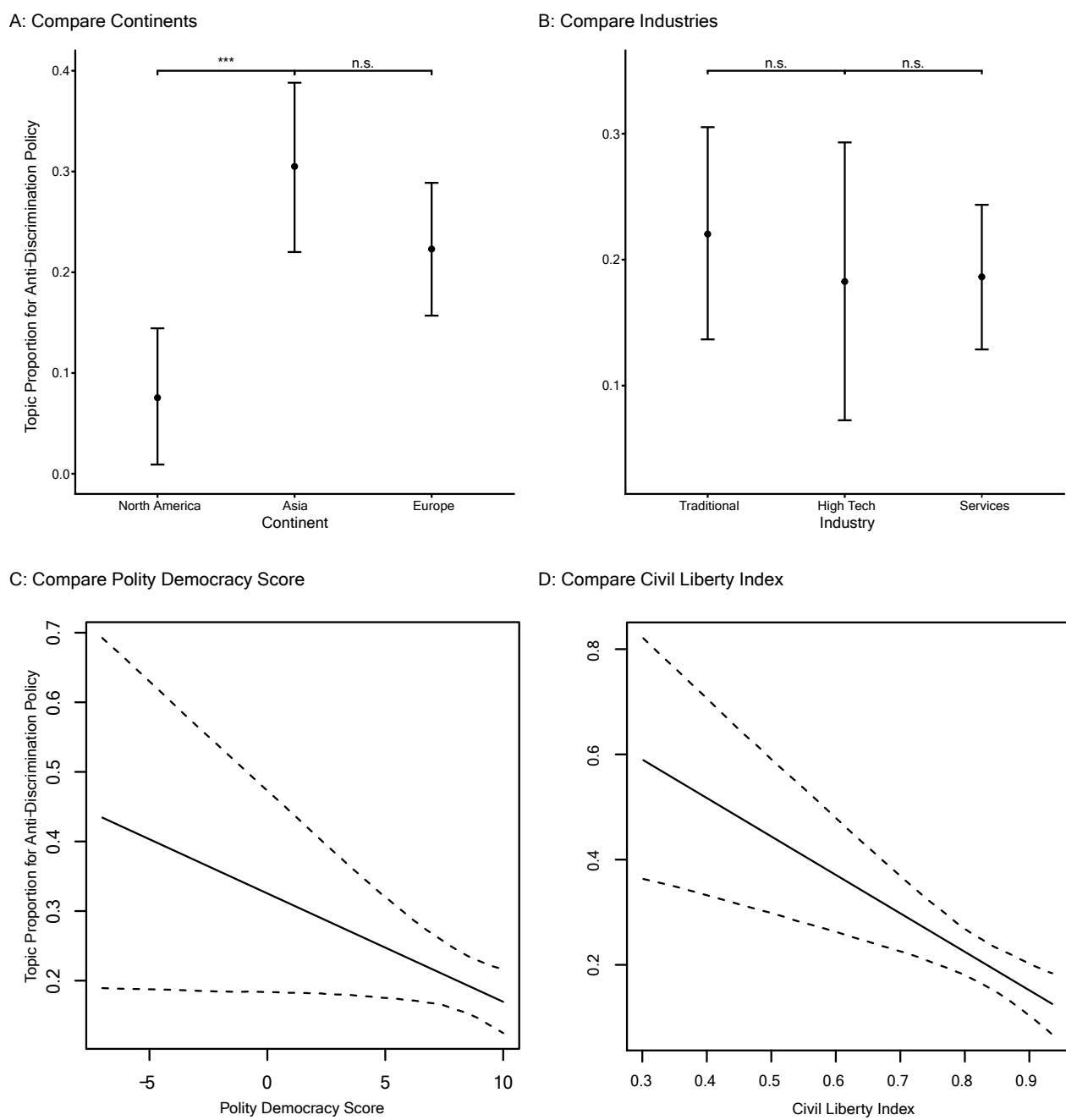

D: Compare Civil Liberty Index

E: Compare Legal Protection Level
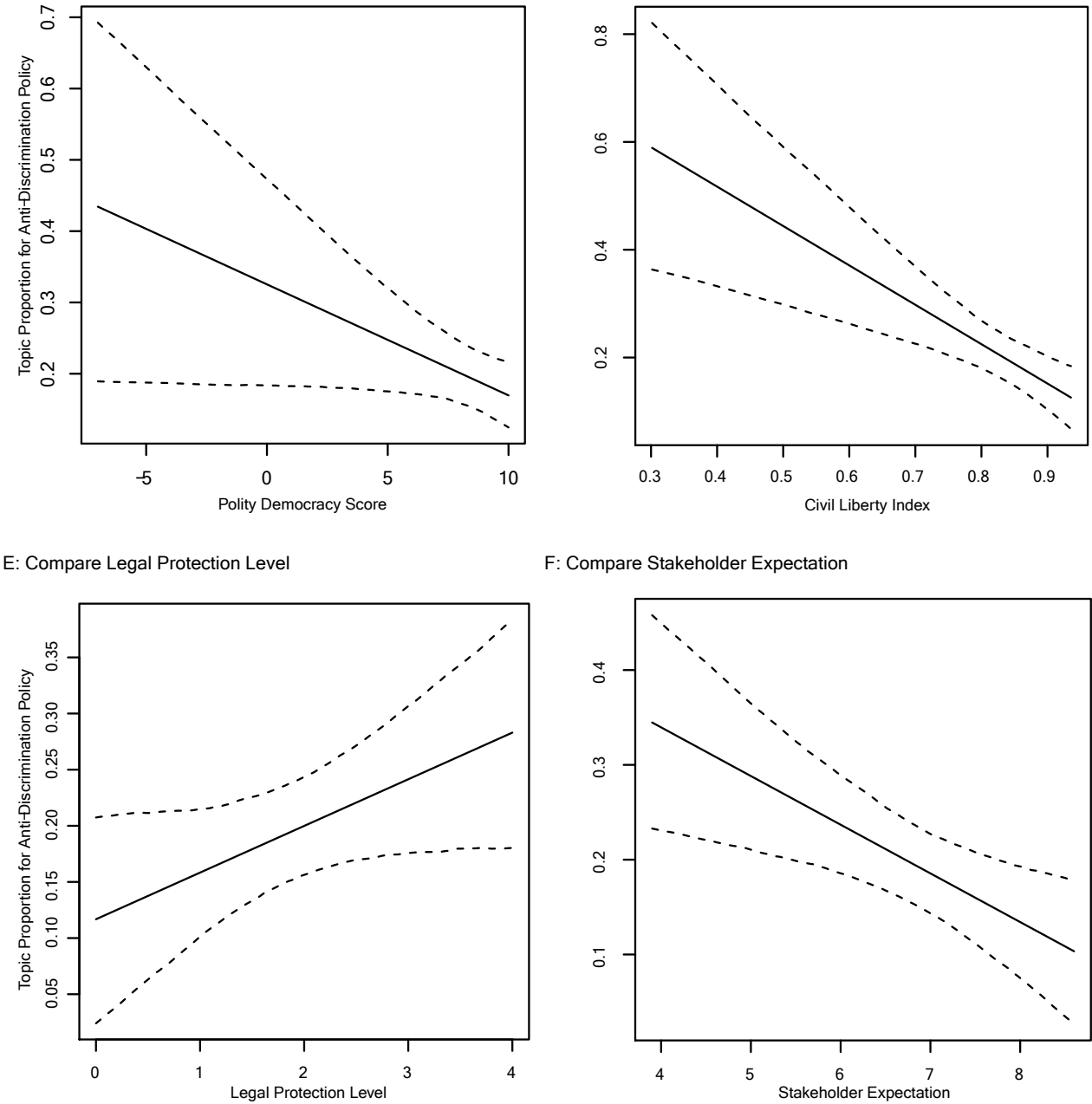

F: Compare Stakeholder Expectation

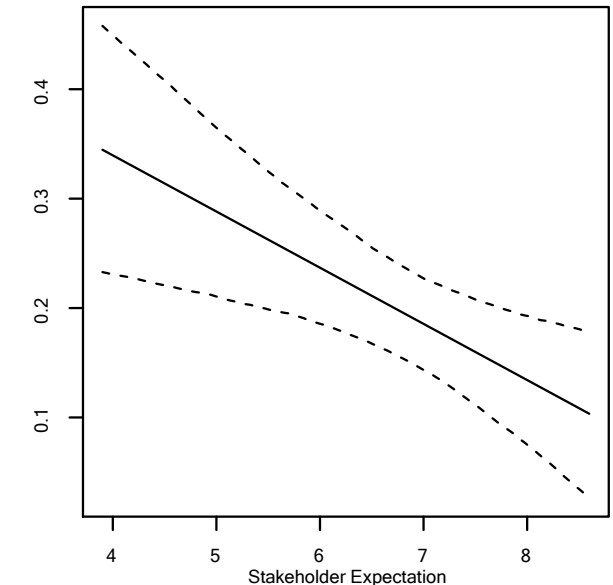

